\title{
Talent czy dar? \\ Kontrowersje teoretyczne i empiryczne wokół zjawiska talentu
}

Kariera otwarta dla talentów, narzędzia w ręce tych, którzy potrafią ich użyć ${ }^{1}$.

\section{Wstęp}

Talent jest dobrem XXI w. - to pogląd, który wygłosił Tony Blair na konferencji Partii Pracy w Bournemouth w roku 1999 (Pocztowski, 2008, s. 36). Wypowiedź polityka znajduje praktyczne uzasadnienie we współczesnym świecie. Coraz częściej mówi się o zdolnościach, uzdolnieniach i talentach w mediach, literaturze, a także w wielu dziedzinach naukowych np. w psychologii i pedagogice (zob. artykuł K. J. Szmidta w tym tomie). Odbywają się konferencje poświęcone tej tematyce, a w wielu krajach emitowany jest program Mam talent, którego celem jest wyłanianie ludzi utalentowanych. Problematyka talentu jest również kluczowa dla organizacji, przedsiębiorstw i firm, które tworzą programy zarządzania talentami. Powyższe działania ukazują rangę zagadnienia, zwłaszcza w Polsce, gdyż w krajach zachodnich zainteresowanie tematyką talentu notuje się już od dłuższego czasu.

W języku polskim słowo talent posiada wiele synonimów. Ze względu na brak konsekwencji w polskiej literaturze przedmiotu, rozważania na temat talentu należy rozpocząć od zdefiniowania pojęć zdolności i uzdolnienia, ponieważ są one wieloznaczne. wierny.

${ }^{1}$ Napoleon I w roku 1817 na Wyspie Św. Heleny podał to jako zasadę, której zawsze był 
Fenomen zdolności należy do najbardziej zajmujących i wieloaspektowych zagadnień w naukach humanistycznych. Ludzie od dawna zastanawiali się nad problemem różnic, jakie obserwowali pomiędzy sobą w szybkości i poprawności myślenia, różnorodności oraz oryginalności pomysłów. Zastanawiano się, dlaczego niektórzy obdarzeni zostali doskonałym słuchem muzycznym, wyczuciem rytmu, pozwalającym na komponowanie wybitnych utworów, inni z kolei tworzą niepowtarzalne dzieła malarskie, podczas gdy większość osób nie wyróżnia się w żadnej z wyżej wymienionych dziedzin, nie mówiąc już o osiąganiu ponadprzeciętnych rezultatów. Na długo przed pojawieniem się naukowego wyjaśnienia ludzie posługiwali się potocznym pojęciem zdolności. Za pomocą tego terminu potrafili sobie wytłumaczyć, dlaczego jednostki wkładające podobny wysiłek w pracę twórczą osiągają gorszy niż inni efekt.

Współczesna psychologia proponuje wiele definicji zdolności. Zbigniew Pietrasiński (1976, s. 736) uważa, że: „zdolnościami nazywamy takie różnice indywidualne, które sprawiają, że przy jednakowej motywacji i uprzednim przygotowaniu poszczególni ludzie osiągają w porównywalnych warunkach zewnętrznych niejednakowe rezultaty w uczeniu się i działaniu”. Z kolei Bronisław Hornowski (1978, s. 48) traktuje zdolności jako „,indywidualne właściwości osobowości człowieka, których nie można sprowadzić do wykształconych nawyków, ale dzięki którym można kształtować różnego rodzaju nawyki, sprawności i umiejętności”.

W polskiej literaturze przedmiotu występują takie określenia, jak: zadatki wrodzone, zdolności, uzdolnienia, zdolności rzeczywiste, zdolności specyficznie ludzkie, talent, zdolności twórcze, wybitne zdolności, cudowne dzieci czy geniusz (Limont, 1994; 2010; Dyrda, 2012), które wskazują na niejednoznaczny charakter pojęcia zdolności.

W literaturze anglojęzycznej można również wyodrębnić kilka określeń zdolności:

- skill (biegłość),

- aptitude (potencjalna możliwość nabycia biegłości czy też umiejętności),

- ability (pojmowane jako aktualne [tu i teraz] możliwości wykonania czegoś, umiejętności ludzkie),

- capacity (potencjalność, zadatki, możliwości [organizmu]),

- prodigy children („,cudowne dzieci”, charakteryzujące się spontanicznym pojawieniem się zdolności, które umożliwiają im aktywność na mistrzowskim poziomie),

- genius (geniusz wyróżniający się rzadkim występowaniem wybitnych zdolności oraz wysokim poziomem zdolności twórczych),

- giftedness (określenie rozróżniające zdolności na ogólne, inteligencję),

- being talented (wskazujące na uzdolnienia specjalne).

Zarówno polskie, jak i anglojęzyczne określenia zdolności można podzielić na dwie grupy ze względu na: 
1) kierunkowość (zdolności, uzdolnienia, talent, zdolności twórcze - aptitude, natural ability, gift, capacity, skills, giftedness, gifted, talented),

2) poziom uzdolnień (wybitne zdolności, cudowne dzieci, geniusz - extraordinary, outstanding, exceptional talent, prodigy child, genius) (Limont, 2010, s.17).

W literaturze tematu można również dostrzec różnorodne podejścia w wyjaśnieniu terminu uzdolnienie. Złożoność pojęcia zdolności i uzdolnień przekłada się na występowanie różnych definicji powyższych terminów. Jednak wielu badaczy traktuje uzdolnienie jako synonim talentu. Bardzo ważne jest, aby nadać precyzyjne thumaczenie obu pojęciom, bowiem ułatwi to przeprowadzenie badań związanych z identyfikacją i wspieraniem zdolności i talentu. Uzdolnienia rozumiane są jako niewyuczone, ponadprzeciętne, naturalne zdolności: „czyli takie właściwości jednostki, które pozwalają na uzyskiwanie wysokich osiągnięć w konkretnej dziedzinie aktywności, na przykład matematyce, muzyce czy plastyce" (tamże, s. 17). M. H. Chruszczewski uzdolnieniom nadaje szerszy zakres znaczeniowy. Badacz traktuje uzdolnienia jako: „określony układ właściwości fizycznych, zdolności oraz innych cech psychicznych człowieka, dzięki którym osiąga on wyraźnie ponadprzeciętne (na tle grupy odniesienia) rezultaty w danej dziedzinie aktywności. Aktywność, o której mowa musi wymagać nie tylko wykonywania operacji elementarnych (co umożliwiają zdolności), czy - ewentualnie określonych zasobów fizycznych, ale też włączenia tych operacji lub zasobów w zorganizowaną sekwencję działań o wyższym stopniu złożoności” (Chruszczewski, 2009, s. 23).

\section{Rys historyczny badań nad uzdolnieniami}

Uzdolnienia oraz talent to słabo zdefiniowane pojęcia w naukach społecznych, przyczyn można upatrywać w tym, że problematyka uzdolnień specjalnych i talentu należy do trudnych zagadnień oraz po części dzięki samej wieloznaczności i niejasności tych terminów. W potocznym rozumieniu uzdolnienia to konkretne osiągnięcia i predyspozycje ludzkie. Funkcjonują w powszechnej świadomości, ponieważ są wszechobecne, czyli występują codziennie w domu, w szkole, w pracy itp.

Warto prześledzić, choćby pokrótce, historię pojęcia wybitnych uzdolnień. $\mathrm{U}$ progu XX w. uzdolnienia specjalne związane były z pojęciem inteligencji, ale gdy zaczęto generalizować inteligencję, termin uzdolnienia specjalne (pojmowane jako właściwość) znikały z pola widzenia. Incydentalnie, gdy badano nie tylko ogólne zdolności umysłowe, ale na przykład genialne osiągnięcia muzyczne, plastyczne czy matematyczne, uzdolnienia specjalne rozumiano jako: „indywidualny typ możliwości, warunkujący powstawanie w rozwijającej się kulturze takich predyspozycji, które sprawiały, iż człowiek mógł odbierać i wytwarzać różne języki ekspresji, komunikowania się i kreacji, oparte na kodzie dźwiękowym, 
językowym, wizualnym, przestrzennym, co umożliwiało mu poznawanie świata i ludzi oraz tworzenia kultury ideowej, materialnej i cywilizacji technicznej" (Popek, 2003, s. 120).

Poglądy na temat uzdolnień specjalnych podlegały historycznym zmianom. Pozytywiści proponowali model oparty na budowie jasnego obrazu umysłu, który pozwalał wyjaśnić mechanizm działań świadomych (podstawowego atrybutu właściwości mentalnych człowieka). Model był związany z główną ideą dotyczącą poznania, sformułowaną jeszcze przez Kartezjusza, który twierdził, że człowiek rozumiany jako byt poznający jest zaopatrzony w różne funkcje, takie jak: zmysły, wyobraźnię, pamięć i intelekt. Jednak to intelekt był najważniejszy, bowiem zapewniał naturalne zdolności poznawania prawdy.

Idąc za tym twierdzeniem badacze od czasów F. Galtona po J. P. Guilforda i R. J. Sternberga prowadzili poszukiwania dotyczące wewnętrznej struktury intelektu i systemu jego funkcjonowania. W tym samym czasie obok intelektu, czyli inteligencji pojawił się termin uzdolnień specjalnych, który bywał zamiennie używany raz jako zdolność, kiedy indziej zaś jako możliwość lub predyspozycje specjalne, choć najczęściej formułowany był jako uzdolnienia specjalne. Tak więc od drugiej połowy XIX w. uczeni zastanawiali się, czy „o możliwościach sprawnościowych człowieka decyduje jedna zdolność ogólna, czy różne uzdolnienia niezależne od siebie, ale decydujące w sumie o jedności zdolności, czy też jedna zdolność ogólna i równocześnie różnorodne uzdolnienia specjalne?" (tamże, s. 121). Powstało wówczas wiele modeli i teorii podejmujących próbę wyjaśnienia fenomenu uzdolnień specjalnych oraz określenia ich inhibitorów i stymulatorów.

Ważnym osiągnięciem teoretycznym była metoda dwuczynnikowej teorii inteligencji C. Spearmana (1904). Badacz rozumiał inteligencję jako ogólną zdolność do spostrzegania zależności oraz wyciągania wniosków (Spearman, za: Pietrasiński, 1975, s. 737). Opis „zdolności” C. Spearman uzyskał na podstawie statystycznej analizy danych z badań testowych i była ona wspólną cechą umysłu, zachowującą stałość w danej populacji, ponieważ wyniki zróżnicowanych testów rozwiązywanych przez rozmaite jednostki były ze sobą w pewnym stopniu powiązane. C. Spearman założył występowanie czynników specjalnych (special - s) z funkcją ogólną (general - g) biorących udział w rozwiązywaniu każdego zadania. Jednak trzeba zaznaczyć, że stopień nasycenia czynnikami g i s był różny i zależał od rodzaju wykonywanego zadania, a także od poziomu rozwoju umysłu jednostki ludzkiej.

Pojęcie inteligencji odwołuje się do dwóch zasadniczych teorii: teorii hierarchicznej, która jest kontynuacją pracy C. Spearmana, oraz teorii czynników równorzędnych.

Teoria hierarchiczna poddana została krytyce ze względu na niemiarodajne wyniki. Badacze otrzymywali zmienną ilość czynników grupowych, ponadto czynniki nie dawały się potwierdzić w praktyce ani w badaniach eksperymentalnych. 
W związku z powyższym pojawiły się alternatywne koncepcje m.in. teoria wieloczynnikowa lub czynników równorzędnych L. L. Thurstona, następnie teoria czynników równorzędnych J. P. Guilforda. Ostatni z wymienionych badaczy wyodrębnił trzy najważniejsze wymiary uzdolnień: percepcyjne, psychomotoryczne i intelektualne. Do wymiarów percepcyjnych zaliczył: wrażliwość poszczególnych organów zmysłowych, uwagę (koncentracja, napięcie, przerzutność - właściwości uwagi rozumianej jako cecha osobnicza warunkująca specyfikę i jakość uzdolnień) oraz percepcję kształtu i ruchu. Wymiary uzdolnień psychomotorycznych zawierają siłę reakcji, impulsywność, szybkość, precyzję, koordynację, gibkość i wytrzymałość. Natomiast wymiary uzdolnień intelektualnych „opierają się głównie na właściwościach funkcji pamięci (pamięć przedmiotów, pamięć symboli, pamięć semantyczna związana z typami percepcyjnymi wzrokowca, słuchowca, pamięcią słowno-ideową) oraz na uzdolnieniach myślenia (uzdolnienia poznawcze, zdolność oceny, uzdolnienia do myślenia twórczego)" (tamże, s. 125).

E. J. Murray opracował jedenaście grup uzdolnień, w których można dojść do wyczynowego poziomu rozwoju. Wymienił następujące uzdolnienia: motoryczne (wszystkie dziedziny sprawności fizycznej oraz zawody wymagające sprawności i zwinności manualnych), mechaniczne (uzdolnienia do manipulowania różnymi urządzeniami i sprawności w posługiwaniu się narzędziami i aparatami), ekonomiczne (planowanie, przewidywanie, realizowanie zadań przynoszących zysk materialny, uzdolnienia menadżerskie), przywódcze (kierowanie, wpływanie na innych ludzi, utrzymywanie dyscypliny itp.), społeczne (pozyskiwanie sympatii, zawieranie przyjaźni itp.), erotyczne, uzdolnienia do pracy umysłowej (np. uzdolnienie do uczenia się i nabywania wiedzy), uzdolnienie do pracy naukowej (np. umiejętność myślenia w kategoriach abstrakcyjnych teorii, naukowych pojęć), uzdolnienia estetyczne (np. umiejętność oceny i artystycznej krytyki), uzdolnienia do działalności twórczej w sztuce (np. uzdolnienie do stwarzania „nowego” w dziedzinie sztuki), uzdolnienia do działalności twórczej w dziedzinie twórczości naukowej (np. stawianie trafnych hipotez); (Murray, za: Popek, 2003, s. 127).

Preludium lat siedemdziesiątych XX w. to rozwinięcie koncepcji zdolności przez jednego z najwybitniejszych psychologów amerykańskich - R. B. Cattella. W oparciu o badania dużych grup za pomocą różnorodnych testów, wyodrębnił on 21 grup uzdolnień, rozumianych jako wspólne czynniki umożliwiające rozwiązywanie zadań testowych. Ponadto jest twórcą triadowej teorii zdolności akcentującej genezę zdolności i uzdolnień. Stanisław Popek (2001) powołuje się na psychologów rosyjskich, którzy wyrażali poglądy analogicznie do poglądów Cattella. S. L. Rubinsztejn, A. N. Leontiew, B. M. Tiepłow oraz W. S. Mierlin, do których odniósł się S. Popek, zajmowali się genezą, rozwojem i realizacją zdolności i uzdolnień w działaniu w określonych warunkach społeczno-ekonomicznych. Posługiwali się przy tym wymiennie pojęciami uzdolnień specjalnych oraz talentu. 
S. L. Rubinsztejn uważał, że niektóre uzdolnienia specjalne w znacznym stopniu różnią się od poziomu zdolności ogólnych (Rubinsztejn, 1964, s. 854), zaś B. M. Tiepłow, odnosząc się do uzdolnień muzycznych, zauważył, że obok zdolności kompozytorskich mogą występować bardzo wąskie specjalne uzdolnienia muzyczne, takie jak specjalne zdolności motoryczne do gry na fortepianie lub na skrzypcach. Równocześnie ze zdolnościami specjalnymi mogą ujawniać się zdolności ogólne na bardzo różnym poziomie (Tiepłow, 1971, s. 226).

Prawie wszyscy wspomniani powyżej autorzy zakładali istnienie (obok integralności zdolności ogólnych i specjalnych) odmiennych właściwości centralnego systemu nerwowego oraz charakterystycznych metod uczenia się $\mathrm{i}$ indywidualnego rozwoju w uzdolnieniach specjalnych. Ponadto posługiwali się wymiennie pojęciami zdolności i uzdolnień. Jednak, co trzeba wyraźnie podkreślić, w przypadku talentu i geniuszu używali sformułowania uzdolnień specjalnych.

Lata $80 . \mathrm{XX}$ w. to okres rozwoju badań nad strukturą i genezą zdolności i uzdolnień specjalnych, ich dynamiką i stabilnością rozwoju. D. H. Feldman, H. Gardner oraz M. Csikszentmihaly jednogłośnie stwierdzili, że uzdolnienia są uwarunkowane genetycznie, rozwijają się i urzeczywistniają w określonym środowisku i w konkretnych uwarunkowaniach historycznych. „Stąd też nie można mówić o człowieku i jego zdolnościach, ale raczej o wzajemnych związkach między kulturowymi uwarunkowaniami oraz jednostkowymi zdolnościami do działania. Autorzy ci uważają, że talent nie jest trwałą i stałą cechą jednostek. Według nich indywidualne możliwości działania wewnątrz określonej dziedziny zmieniają się w ciągu życia pojedynczego człowieka - zatem wyniku z testów pięcioletniego dziecka nie można traktować jako predykatora osiągnięć w wieku dojrzałym, zaś zróżnicowanie talentów związane jest z odmiennością konkretnych dziedzin, z ich wewnętrzną strukturą, zmianami zachodzącymi w tych dziedzinach na przestrzeni czasu" (Limont, 1994, s. 37-38). Przytoczona opinia sugeruje, że czynnikiem determinującym określone rodzaje uzdolnień jest w znacznej mierze charakter epoki oraz intensyfikacja rozwoju kultury. Podobnie uważa B. Bloom, sądząc, że wspólnym mianownikiem rozwoju różnych talentów, np. naukowych, artystycznych czy sportowych, jest stymulujący wpływ środowiska rodzinnego, a także wysoki poziom edukacji (Bloom, 1985, s. 24-25). J. Strelau (1997, s. 58), powołując się na badania M. B. Tiepłowa, wnioskuje, że istnieje tyle rodzajów zdolności, ile kategorii działalności ludzkiej można wyodrębnić. Dodaje przy tym, że pojawiające się nowe rodzaje działalności generują nowe uzdolnienia, np. menadżerskie, operatorskie, które w poprzedniej epoce nie były uważane za zdolności. Zdaniem Strelaua jest to proces obustronny, czyli że w ujęciu diachronicznym niektóre uzdolnienia zanikają albo w ogóle się nie uwidaczniają. 


\section{Rozróżnienie pojęć giftedness i talent}

Często dar jest niewielki, ale skutek z niego ogromny.

Seneka Młodszy

Istnieje konfuzja dotycząca przekładu anglojęzycznej terminologii pojęć giftedness i talent na język polski. Ponadto pojęcia uzdolnienie i talent wyjaśniane są w różny sposób w literaturze naukowej. Poniżej podejmę próbę wyklarowania niektórych wątpliwości i dokładnego wyjaśnienia znaczenia obu pojęć.

Terminy obcojęzyczne są bardzo trudne do przełożenia na język polski, ponieważ zależne są od kontekstu i uwarunkowań kulturowych, w jakich kształtowało się ich rozumienie. W przekładzie pojęć ability, aptitude i capacity na język polski występuje powszechna zgodność w thumaczeniu i w rozumieniu tych terminów. Jednak już przy wyjaśnianiu pojęć gifted i talented pojawia się trudność, gdyż w literaturze naukowej występuje dwuznaczność i niejasność w rozróżnianiu pojęć giftedness i being talented. Françoys Gagné2 dostrzegając tę ambiwalencję uznał, że określenie giftedness ,związane jest z posiadaniem i spontanicznym manifestowaniem niewyuczonych, naturalnych ponadprzeciętnych zdolności i predyspozycji (zwanych uzdolnieniem)", a talent jako „ponadprzeciętne mistrzostwo systematycznie rozwijanych zdolności (lub sprawności) w przynajmniej jednej dziedzinie ludzkiego działania" (Gagné, 2008, s. 1). Nie wszyscy autorzy przestrzegają tego podziału, ponieważ bardzo często spotyka się rozumienie gifted jako uzdolniony i utalentowany. W niektórych pracach naukowych można spotkać jednakowe rozumienie pojęcia giftedness i talent. Podczas gdy inni autorzy rozróżniają zdolności na te poznawcze (giftedness) oraz wyższy poziom zdolności rozumiany jako talent.

W potocznym rozumieniu nie można jednoznacznie odróżnić obydwu pojęć, co więcej są mylone nie tylko w ujęciu kolokwialnym, ale także słownikowym poprzez tłumaczenie terminów gifted i talented jako „utalentowany”3. W literaturze naukowej utrwala się ta sama dwuznaczność. Napotyka się użycie obydwu pojęć na przemian w tym samym akapicie, co sugeruje, że są one synonimami. Zaledwie kilku autorów podjęło próbę wyraźnego ich rozróżnienia, m.in. A. Harry Passow (1995) 4 i Françoys Gagné. Tłumacząc obydwa terminy na język polski, należy

${ }^{2}$ Françoys Gagné pochodzi z Montrealu. Prowadzi prace badawcze m.in. na temat talentu, wpływu różnych czynników na rozwój talentu. Jest autorem modelu The Differentiated Model of Giftedness and Talent (DMGT), w którym rozróżnia zjawisko daru i talentu.

${ }^{3}$ Wielki Stownik PWN - OXFORD, Wydawnictwo Nauowe PWN S.A. i Oxford University Press, Warszawa 2006.

${ }^{4}$ A. Harry Passow to jeden z pierwszych nauczycieli , który zbadał potrzeby intelektualne dzieci posiadające dar. Passow jest autorem pracy Planning for Talented Youth: Considerations for Public 
zaznaczyć, że w przypadku słowa talented, talent istnieje polski odpowiednik thumaczony jako: talent. Jednak thumaczenie słowa gifted jest bardziej skomplikowane, bowiem termin gifted rozumiany jest jako uzdolniony, ale równie często jako utalentowany. Dlatego należałoby rozróżnić te dwa pojęcia i nadać im precyzyjne tłumaczenie w języku polskim. Przyjmując, że pojęcie uzdolnienie wyjaśniane jest w literaturze naukowej jako ponadprzeciętne zdolności, nie można tym samym thumaczyć słowa gifted jako utalentowany, ponieważ to pojęcie dotyczy naturalnych zdolności (natural, genetic abilities), predyspozycji (aptitudes), zaś właśnie talent jest określany jako ponadprzeciętne mistrzostwo systematycznie rozwijanych naturalnych zdolności i uzdolnień czy uzdolnienie związane z systematycznym rozwijaniem umiejętności (Limont, 2010). Konieczność takiego precyzyjnego rozróżnienia dobrze puentują wypowiedzi artystów, którzy wyrażają swoją opinię na ten temat na forum internetowym. Poniżej dosłownie przedstawiam niektóre wypowiedzi:

- I feel that being gifted comes naturally as in musical abilities (as in art, etc). Some children are gifted in the audio aspect of learning music, hence they become rapid learners. To be talented in playing an instrument takes skill and a musical background [Uważam, że uzdolnienie bywa naturalne tak jak muzyczne zdolności (np. w sztuce itp.). Niektóre dzieci posiadają dar słyszenia muzyki, dzięki temu szybko się uczą. Talent w grze na instrumencie wymaga i umiejętności i muzycznego zaplecza - tłum. aut.];

- Being gifted comes from within, not from the environment. A person can be musically inclined, yet the talent has to be developed over time [Bycie uzdolnionym pochodzi z wewnątrz, nie z otoczenia. Jednostka może mieć skłonność do muzyki, ale trzeba czasu by rozwinął się talent - thum. aut.];

- Gifted is being able to hit a target no one else can [Być uzdolnionym to trafić w tarczę lepiej niż ktokolwiek inny - thum. aut.];

- I think of gifted more as mental ability. Talent as more of a skill or being more dexterous. Maybe with talent a person can just naturally do something, but something skill-related. Gifted would be someone being able to work on something more taxing and get better results [Uzdolnienie przywodzi na myśl zdolność raczej intelektualną. A talent raczej umiejętność czy zręczność w działaniu. Być może utalentowany człowiek potrafi coś zrobić naturalnie, ale będzie to związane z umiejętnościami. Osoba uzdolniona jest w stanie pracować nad czymś, wkładając $w$ to więcej wysiłku i osiągać przy tym lepszy rezultat - tłum. aut.] $]^{5}$.

Powyższe poglądy artystów muzyków pochodzą z obserwacji ich środowiska zawodowego, artystycznego i są dowodem na to, że istnieje wyraźna różnica pomiędzy pojmowaniem terminów gifted i talented. Ludzie spontanicznie wypowiadając się na ten temat są w stanie rozróżnić te dwie cechy jako odrębne.

Schools (Teachers College Press, 1955), w której zaproponował program edukacyjne dla najbardziej utalentowanych studentów.

${ }^{5} \mathrm{http}: / /$ www.pianostreet.com/smf/index.php?topic $=32875.0$ 
Zakładając, że uzdolnienia wyjaśniane jako układ zdolności, predyspozycji i cech psychicznych człowieka, które ujawniając się spontanicznie we wczesnym dzieciństwie pozwalają, na przykład, na szybkie opanowanie umiejętności pisania, czytania czy nauki różnych języków obcych, proponuję przekład angielskiego słowa gifted na język polski jako uzdolniony. Biorąc pod uwagę, że angielski rzeczownik słowa gift rozumiany jest jako „dar”, logicznym wydaje się również thumaczenie przymiotnika gifted jako „obdarzony”, posiadający dar. Ponadto, nawiązując do wypowiedzi F. Gagné, który uważa, że „these two definitions go far beyond a single contrast between intellectual and another kinds of abilities: they also imply a distinction between innate versus acquired abilities and between capacity and performance" [Te dwie definicje znacznie wykraczają poza binarne przeciwieństwo pomiędzy intelektualnymi zdolnościami a zdolnościami innego rodzaju. Implikują również rozróżnienie pomiędzy wrodzonymi, a nabytymi zdolnościami oraz pomiędzy potencjałem, zdatnością do czegoś, a działaniem - tłum. aut.] (Gagné, 1985, s. 104). W tym rozumieniu zdecydowanie wykluczyć należy thumaczenie słowa gifted jako utalentowany.

Godne uwagi jest specyficznie polskie rozumienie słowa talent w kontekście uwarunkowań historycznych i kulturowych. W potocznym rozumieniu termin talent bywa rozumiany dwojako: albo jako dar, coś wrodzonego, z czym człowiek się rodzi i albo to ma, albo nie, bądź też coś nad czym pracuje i co kształci w ciągu swojego życia. Rozumienie zakresu pojęcia dar nie jest więc tożsame $\mathrm{z}$ angielskim pojęciem gifted. Ta dwuznaczność w rozumieniu pojęcia mogła powstać przez zaniechanie w pewnym okresie użycia słów dar, uzdolniony, obdarzony. W słowniku języka polskiego istnieje słowo dar, które jeszcze w dwudziestoleciu międzywojennym było często używanym słowem. W czasach PRL, z powodów ideologicznych, termin dar został wyparty z powszechnego użycia. Przy analizie semantycznej staje się oczywiste, że człowiek nie ma na dar wpływu, że został naturalnie obdarzony czymś (po części genetycznie), czego nie może wykształcić. Takie wyjaśnienie było z oczywistych względów ideologicznie niewygodne, ponieważ wszystko, co człowiek osiągał miało być związane z ,pomocą” drugiej osoby (edukatora, nauczyciela, towarzysza z organizacji partyjnej czy ZMP), którzy byli „ideologicznie właściwymi” sprawcami, inicjatorami, inspiratorami osiągnięć ludzkich.

Można przytoczyć wiele przykładów artystów uzdolnionych, posiadających dar. Jednym z nich był malarz ,prymitywny” raczej niż „prymitywista”, Nikifor Krynicki. Był samoukiem, swój styl wypracowywał samodzielnie. Malował

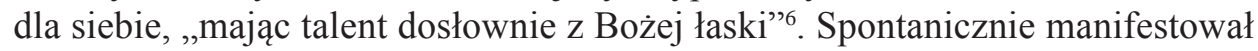
wrodzone, ponadprzeciętne zdolności i nie odczuwał potrzeby korzystania z jakiejkolwiek instytucjonalnej pomocy ani w sferze doskonalenia warsztatu, ani promocji swej twórczości. Tworzył ulotne obrazy na serwetkach w kawiarni i pudełkach po papierosach. Szybko został rozpoznany przez pielgrzymujących

${ }^{6} \mathrm{http}: / /$ www.malarze.com/plartysta.php?id=245\&biografia=f\&l=pl 
do niego znawców sztuki, obdarzał swym malarstwem każdego, kto zaprosił go na obiad albo na kufel piwa. Mimo że „prymitywizm” był kierunkiem „słusznym” i popieranym przez ówczesny ustrój polityczny, to jednak Nikifor tworzył i zmarł w ,instytucjonalnym” zapomnieniu. Odrzucając (z premedytacją bądź z niewiedzy) ,pomocną dłoń” PRL-owskich państwowych mecenasów i edukatorów, skazał się na niebyt wśród uznanych talentów, choć jego dar był oczywisty.

Tymczasem Aleksander Kobzdej zaliczany jest do grupy określanej mianem utalentowanych. Kształcony w Lejdzie pod okiem W. Lama, po wojnie studiował na ASP w Krakowie. Choć najpierw malował w duchu postimpresjonistycznym, z końcem lat 40-tych XX w. w jego twórczości zaczęły przeważać motywy realistyczne. Wkrótce Kobzdej został okrzyknięty malarzem numer $1 \mathrm{w}$ dobie socrealizmu, w której został oficjalnie zadekretowany przez władze komunistyczne. W tym okresie swojej twórczości był typowym autorem jednej z najbardziej znanych malarskich realizacji postulatów realizmu socjalistycznego, realizatorem symbolu tego czasu i jednego z najsławniejszych obrazów Podaj ceglę ${ }^{7}$. Niewątpliwie obdarzony talentem, A. Kobzdej, poświęcił całe życie na systematyczny rozwój zdolności, sprawności w dziedzinie malarstwa, który doprowadził go do mistrzostwa. Świadomie korzystał przy tym z instytucjonalnego wsparcia państwa. Dziś jest zaliczany do grupy tych twórców, którzy, oprócz systematycznie rozwijanych zdolności, zostali poniekąd stworzeni na potrzeby ducha czasu tamtej epoki. Obecnie pojęcie talentu jest nadal aktualne zarówno w rozumieniu potocznym, jak i akademickim, chociaż, z uwagi na konfuzję terminologiczną - jest używane w różnych znaczeniach, o czym pisałam powyżej.

Być może jest to za daleko idąca hipoteza. Faktem jest jednak, że gdy w literaturze anglojęzycznej istnieją wyraźnie odrębne terminy gifted i talented, to w polskich pracach brakuje konsekwentnie stosowanego odpowiednika słowa gifted, który umożliwiłby wyodrębnienie tych dwóch zjawisk.

Dla ułatwienia dyskursu naukowego warto temu zaradzić. Przychylając się do definicji Françoys Gagné (2004, s. 1), podkreślę, że osoby uzdolnione, które posiadają dar ,spontanicznie manifestują niewyuczone, naturalne ponadprzeciętne zdolności, podczas gdy osoby utalentowane wykazują ponadprzeciętne mistrzostwo w systematycznie rozwijanych zdolnościach (lub sprawnościach) w przynajmniej jednej dziedzinie ludzkiego działania". Porównując oba zjawiska do dziedziny fizyki, można uznać, że dar ma wartość potencjalną, zaś talent to wymiar „kinetyczny”, realizacja daru, świadoma, ukierunkowana, modulowana (równa pracy, jaką trzeba wykonać, aby uzyskać odpowiedni układ).

Spróbujmy zatem wyjaśnić, jak pojęcia uzdolnienia i talentu różnią się od siebie w literaturze naukowej różnych obszarów językowych. $Z$ uwagi na istotne znaczenie teoretyczne tego rozróżnienia opisanych wyżej pojęć - anglojęzyczne słowo gifted będę odtąd tłumaczyła jako uzdolniony. Potocznie również można przetłumaczyć powyższe słowo jako obdarzony darem, posiadający dar.

\footnotetext{
${ }^{7} \mathrm{http}: / /$ www.culture.pl/pl/culture/artykuly/os_kobzdej_aleksandersocrealistycznym
} 


\title{
Istota talentu. Polemika teoretyczna
}

\begin{abstract}
Dajcie mi tuzin zdrowych niemowląt, bez wad wrodzonych, i pozwólcie mi je umieścić w określonym przeze mnie środowisku, a gwarantuję, że wylosuję jedno z nich i zrobię z niego dowolny typ specjalisty, jaki sobie założę - doktora, prawnika, artystę, menadżera, a nawet żebraka, bez względu na jego wrodzone talenty, skłonności, tendencje, możliwości, powołania i rasę jego przodków.
\end{abstract}

John B. Watson

A zatem czym jest talent? Intuicyjne rozumienie tego pojęcia nie wystarcza nam do zdiagnozowania talentu w danej dziedzinie twórczości. Czy głęboka pasja i zainteresowania to już talent? Czy gdy człowiek coś robi, zaczyna to lubić, to jego zdolność zamienia się w talent? Jakie są kryteria talentu? W szerszym kontekście naukowym zrozumienie i wyjaśnienie zjawiska wymaga podejścia interdyscyplinarnego, tym bardziej że, jak widzieliśmy powyżej, wokół pojęcia talentu powstało wiele kontrowersji i trudności nomenklaturowych.

Można śmiało stwierdzić, że od zarania dziejów człowiek miał pogląd, czym jest zjawisko współcześnie określane mianem talentu. W starożytnej Grecji zjawisko inspiracji, które warunkowało sukces, określano mianem natchnienia Muz. Kontynuatorzy myśli platońskiej uznali, że całe prawdziwe poznanie, cała wiedza jest wrodzona, a współcześnie mówiąc - uwarunkowana genetycznie. Arystoteles sformułował pogląd, który podkreślał istotę determinującą sukces, zaznaczając przy tym, że pielęgnowanie, bardziej niż natura człowieka, jest kluczem do natury człowieka. Konfucjusz opracował teorię podkreślającą rolę wysiłku przy dochodzeniu do wielkich osiągnięć. A zatem etymologia słowa talent sięga czasów starożytnych. Słowem fundamentalnym dla dalszych rozważań jest termin w języku greckim $\tau £ \lambda \alpha v \tau o v, t O ̀$ - oznaczający wagę (jednostka wagi w Atenach ok. $26 \mathrm{~kg}$ lub suma pieniędzy równa talentowi złota, srebra; talent zawierał $60 \mathrm{~min}, 6000$ drachm, 36000 oboli); (Słownik grecko-polski, 2001, s. 380). Słowo talent należy do europeizmów, jest wypadkową z języka łacińskiego i greckiego ${ }^{8}$. Talent był jednostką wagi używaną przez wiele starożytnych cywilizacji m.in. hebrajską, egipską, grecką i rzymską. Był nazwą wielu starożytnych jednostek masy np. talent babiloński (3600 szekli), talent palestyński i syryjski (3000 szekli), talent grecki (6000 drachm).

\footnotetext{
${ }^{8}$ Schemat: wartość monetarna - cenny dar - przymiot, dar przyrodzony - wybitne uzdolnienia (Nowy słownik etymologiczny języka polskiego, 2003, s. 493-494).
} 
Słownik etymologiczny języka polskiego podaje, że słowo talent jest: „,europejską przenośnią z łac. talentum, od grec. talanton. Nazwa wagi i srebrnej monety od pnia oznaczającego „ciężar, nosze” łac. tollo, tolero 'znoszę', niem. „Gulden” (Stownik etymologiczny języka polskiego, 1985, s. 564). Słownik wyrazów obcych W. Kopalińskiego podaje, że były to starożytne jednostki monetarne o wartości talentu złota albo srebra. Warto podkreślić, że ówczesne jednostki monetarne to kruszce metali szlachetnych. Porównując ówczesny talent do współczesnego rozumienia, można stwierdzić, że jedno pozostało bez zmian - jego waga i wartość.

Biblijna przypowieść o talentach z Ewangelii św. Mateusza, w której głównymi bohaterami są pan i jego trzej słudzy jest pierwszą metaforą, w której pojawia się słowo talent. Pan, udając się w podróż, wzywa do siebie sługi i dzieli pomiędzy nich prawdziwy majątek. Jeden dostaje pięć talentów, drugi dwa, a trzeci jeden - każdy proporcjonalnie do swoich zdolności (należy zwrócić uwagę, że w ówczesnych czasach talent był jednostką wagi i wynosił mniej więcej od 34 do 43 kilogramów). Po powrocie pan dowiaduje się, co słudzy uczynili z jego majątkiem. Pierwszy wykazał się umiejętnościami handlowymi i podwoił pięć talentów o kolejne pięć. Drugi podobnie do poprzednika pomnożył swoje dwa talenty o kolejne dwa. Tymczasem sługa, który otrzymał jeden talent, w obawie przed utratą złota, zakopał pieniądze. Po wysłuchaniu opowieści sług, pan chwali dwóch pierwszych za właściwe wykorzystanie majątku, a trzeciemu udziela reprymendy za bezczynność i próżniactwo, dodając: odbierzcie mu ten talent, a dajcie temu, który ma dziesięć talentów. Każdemu bowiem, kto ma, będzie dodane, tak, że nadmiar mieć będzie (Mt 25, 14-30). Oprócz interesującej i niezwykle płodnej metafory przypowieść ta wskazuje, że w okresie biblijnym wysoko ceniono szczególne umiejętności. Biblijne ujęcie można porównać do talentu rozumianego współcześnie jako specjalne uzdolnienia. Już wtedy uważano, że osoby, które otrzymają więcej mogą z pomocą niewielkiego wysiłku wiele osiągnąć, a ci, którzy nie są równie utalentowani mogą osiągnąć tyle samo poprzez ciężką pracę. Na krytykę zasługują ci, którzy pomimo posiadania talentu nie wykorzystują i nie rozwijają go. Ujęcie takie podkreśla, że motywacja do inwestowania w samorozwój intelektualny oraz wysiłek związany z intensywną pracą są niezbędne do rozwijania talentu.

Podobny punkt widzenia przedstawia ekspert w dziedzinie przywództwa, publikujący w „New York Times” John C. Maxwell, autor książki Talent is never enough: discover the choices that will take you beyond your talent. Wspomniany autor twierdzi również, że talent należy rozwijać; , [ [...] talent is God-given gift that should be celebrated" [talent jest darem od Boga, który powinien być celebrowany - thum. aut.] (Maxwell, 2008, s. 3). J. C. Maxwell wymienia trzynaście cech (wiara, pasja, inicjatywa, koncentracja, przygotowanie, praktyka, wytrwałość, odwaga, umiejętność uczenia się, charakter, związek i zależności, odpowiedzialność i praca zespołowa), które pozwolą każdemu wykorzystać maksymalnie swoje możliwości. Podkreśla przy tym, że można mieć talent, ale nie rozwijając go, traci się szansę na wybitne osiągnięcia. Autor uważa, że sam talent (clear talent) to nie wszystko, trzeba mieć 
jeszcze talent-plus. Połączenie czystego talentu z ciężką pracą oraz odpowiednimi cechami charakteru jest dopiero drogą do sukcesu i wybitnych osiągnięć ${ }^{9}$. Autor przytacza wypowiedzi filozofów, psychologów, pisarzy, którzy potwierdzają jego tezę, że clear talent to nie wszystko. Jedna z tez filozofa Ralpha Waldo Emersona głosi, że: ,[...] talent for talent's sake is a bauble and a show. Talent working with joy in the cause of universal truth lifts the possessor to a new power as a benefactor" [talent dla samego talentu jest jak miedź brzęcząca, jak cymbał brzmiący. Talent w parze z pasją odkrywania prawd najwyższych nadaje jego posiadaczowi moc dobroczyńcy - thum. aut.] (Emmerson, za: Maxwell, 2008, s. 5). Dlatego talent należy cenić, ale aby dokonać wybitnych osiągnięć, należy łączyć go z ciężką pracą, dbać o niego i go rozwijać. Podsumowaniem powyższych poglądów niech będzie zdanie pisarza Stephena Kinga, który pisze: ,talent is cheaper than table salt. What separates the talented individual from the successful one is a lot of hard work" [Talent jest tani jak barszcz. Co odróżnia gościa z talentem od faceta odnoszącego sukces, to kawał ciężkiej roboty - tłum. aut.] (King, za: Maxwell, s. 6).

Definicja słownikowa określa talent jako niezwykłą, nieprzeciętną zdolność twórczą; wybitne uzdolnienia do czegoś (Słownik języka polskiego, 1983). W słowniku wyrazów obcych W. Kopaliński definiuje talent jako wybitne uzdolnienia specjalne do poczynań twórczych, albo odtwórczych (Kopaliński, 2007, s. 273). Uciekając się do metonimii, wielkim talentem można nazwać człowieka, który obdarzony jest takimi uzdolnieniami (tamże).

W psychologii talent bywa rozpatrywany z różnych punktów widzenia. J. Strelau (1997, s. 232) uważa, że talent to „wybitne zdolności ogólne i (lub) specjalne urzeczywistniające się dzięki interakcji z innymi czynnikami (wewnętrznymi i zewnętrznymi) w określonej działalności człowieka". Dodatkowo J. Strelau wymienia determinanty warunkujące rozwój talentu. Do pięciu czynników wymienionych przez A. J. Tannenbauma dodaje szósty, dowodząc, że talent to suma interakcji przynajmniej sześciu czynników. Są to:

1) zdolności ogólne (zdolność rozumowania i wnioskowania stanowiące meritum inteligencji, są niezbędnym czynnikiem warunkującym rozwój każdego rodzaju talentu),

2) określona siatka uzdolnień kierunkowych,

3) czynniki nie związane z myśleniem - struktura osobowości warunkująca efektywność działania (np. silna motywacja, koncentracja),

4) środowisko społeczne (rodzina, szkoła, instytucje itp.),

${ }^{9}$ Podobną myśl można znaleźć w dialogu Platona „Fajdros: [...] Kto bez tego szału Muz, do wrót poezji przystępuje, przekonany, że dzięki samej technice będzie wielkim artystą, ten nie ma święceń potrzebnych i twórczość szaleńców zaćmi jego sztukę z rozsądku zrodzoną" (Platon, 2002, s. 34). Cytat Platona jest często przywoływany dla podkreślenia związków twórczości (poezji) z obłędem, ale można go interpretować również jako twierdzenie, że same zdolności nie wystarczą do wybitnych osiągnięć. Trzeba wziąć pod uwagę całą osobowość człowieka, jego cechy charakteru, motywacje i emocje. Taki sposób interpretacji cytatu Platona również przywołuje w swojej pracy M. H. Chruszczewski. 
5) czynnik losowy (talent ma największą szansę rozwoju w momencie, w którym jednostka o wybitnych zdolnościach w określonej dziedzinie znajduje się we właściwym miejscu i we właściwym czasie),

6) myślenie twórcze rozwinięte na wysokim poziomie (podobnie jak inteligencja jest ogólnym warunkiem rozwoju talentu).

J. Strelau wpisuje definicję talentu w wyjątkowe możliwości człowieka i konkretne działanie. Dostrzega korelacje pomiędzy zdolnościami ogólnymi (inteligencją) a zdolnościami specjalnymi. J. A. Achter i D. Lubinski (2005) przypisują talent osobie, która w sposób lepszy niż inni rozumie własne, niecodzienne zainteresowania i predyspozycje, a ponadto potrafi dostrzec ich związek z możliwościami kształcenia i pracy zawodowej. Osoba utalentowana według tych autorów charakteryzuje się myśleniem refleksyjnym, dzięki któremu zdaje sobie sprawę, w jakim stopniu pielęgnowanie swoich indywidualnych cech może wpływać na jej rozwój w przyszłości. J. W. Dawid za talent przyjmuje spotęgowane uzdolnienia. Dotyczą kilku lub wielu różnorodnych dyscyplin oraz mogą mieć ukierunkowany, wysoce specjalistyczny charakter. Podobny punkt widzenia przyjmuje Michał Hubert Chruszczewski (2009, s. 27), który uważa, że „talent to taki układ właściwości fizycznych, zdolności oraz innych cech psychicznych człowieka, dzięki którym osiąga on wybitne (na tle grupy odniesienia) rezultaty w danej dziedzinie aktywności. Talent jest więc nie pojęciem odrębnym względem uzdolnienia, lecz szczególnym uzdolnienia przypadkiem”.

Kolejnym badaczem talentu jest Karen Rogers (2002, s. 46), która uważa, że różni się on od zdolności tym, że jest zawsze zdolnością nadzwyczajną, niepospolitą, bardzo rzadko występującą, jest zdolnością twórczą, ujawniającą się w szczególnie wybitnych osiągnięciach w konkretnej dziedzinie.

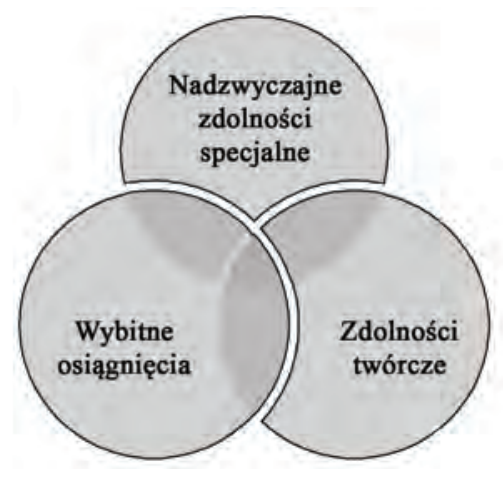

Rys. 1. Talent według K. Rogers

Źródło: K. Rogers, 2002, s. 46

Rysunek 1. przedstawia talent rozumiany według K. Rogers. Jest to zespolenie zdolności twórczych, wybitnych osiągnięć jednostki oraz uzdolnień specjalnych, wśród których znajduje się talent. Talent jest rozumiany jako specyficzny kompleks 
cech indywidualnych, pojawiający się już w okresie wczesnego dzieciństwa u niewielu osób, prowadzący do niezwykłego mistrzostwa w pewnej dziedzinie.

R. E. Bernacka (1999, s. 104) jest zdania, że nie każda osoba uzdolniona może mieć talent, ale każda osoba $\mathrm{z}$ talentem musi mieć uzdolnienia specjalne, i to na wysokim poziomie.

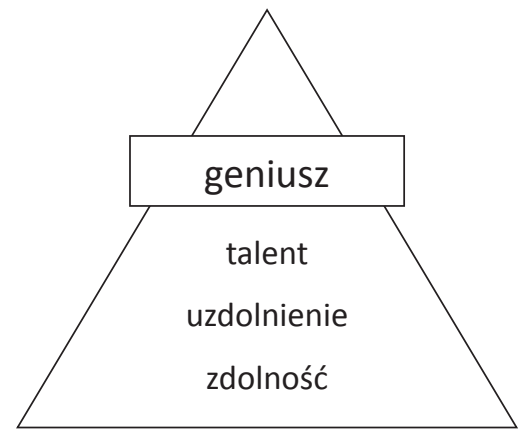

Rys. 2. Hierarchiczny układ pojęć

Źródło: R. E. Bernacka, 2006, http://www.wychowawca.pl/miesiecznik_nowy/2006/01-2006/01.htm

R. E. Bernacka uważa, że aby talent mógł się rozwinąć, jednostka musi posiadać zdolności twórcze na wysokim poziomie, a jej poziom inteligencji powinien być powyżej przeciętnej. Niezbędna jest odpowiednia osobowość, zabezpieczająca efektywność działania oraz wspomniany już u J. Strelaua czynnik losowy rozumiany jako łut szczęścia, właściwe miejsce i czas. Zatem jak rozpoznać talent? Zdaniem Bernackiej talent przejawia się w twórczej działalności człowieka. Tak na przykład, aby powstał utwór muzyczny niezbędne są słowa, muzyka i wykonanie. Jeśli ktoś pięknie śpiewa, ale nie jest twórcą utworu, to można powiedzieć, że jest uzdolniony, ale nie ma talentu. Talent charakteryzuje ludzi twórczych i jest niejako podsumowaniem ich dorobku (tamże, s. 104). Odnosząc się dla przykładu do polskiej muzyki rozrywkowej na miano talentu zasługują z pewnością Marek Grechuta, Ewa Demarczyk czy Czesław Niemen.

Erika Landau (2003, s. 61) rozumie i thumaczy talent przez pryzmat swojej wieloletniej pracy z dziećmi utalentowanymi. Dziecko takie, według autorki, jest: bardziej ciekawe świata i ruchliwe, bardziej spragnione przygód, samodzielne i skłonne do zabawy, potrafi lepiej powiązać ze sobą różne sprawy itp. E. Landau opracowała holistyczne podejście do talentu.

Autorka uważa, że talent jest działaniem wynikającym z pełni osobowości, w której świat zewnętrzny jest zintegrowany ze światem własnym dziecka (tamże, s. 198). Holistyczne podejście do talentu zakłada, że dzięki kreatywności talent i inteligencja wzbogacone zostają o duchową dojrzałość i dialog interpersonalny, tworząc pełną zintegrowaną osobowość zdolną do całkowitego wykorzystania swoich możliwości. 


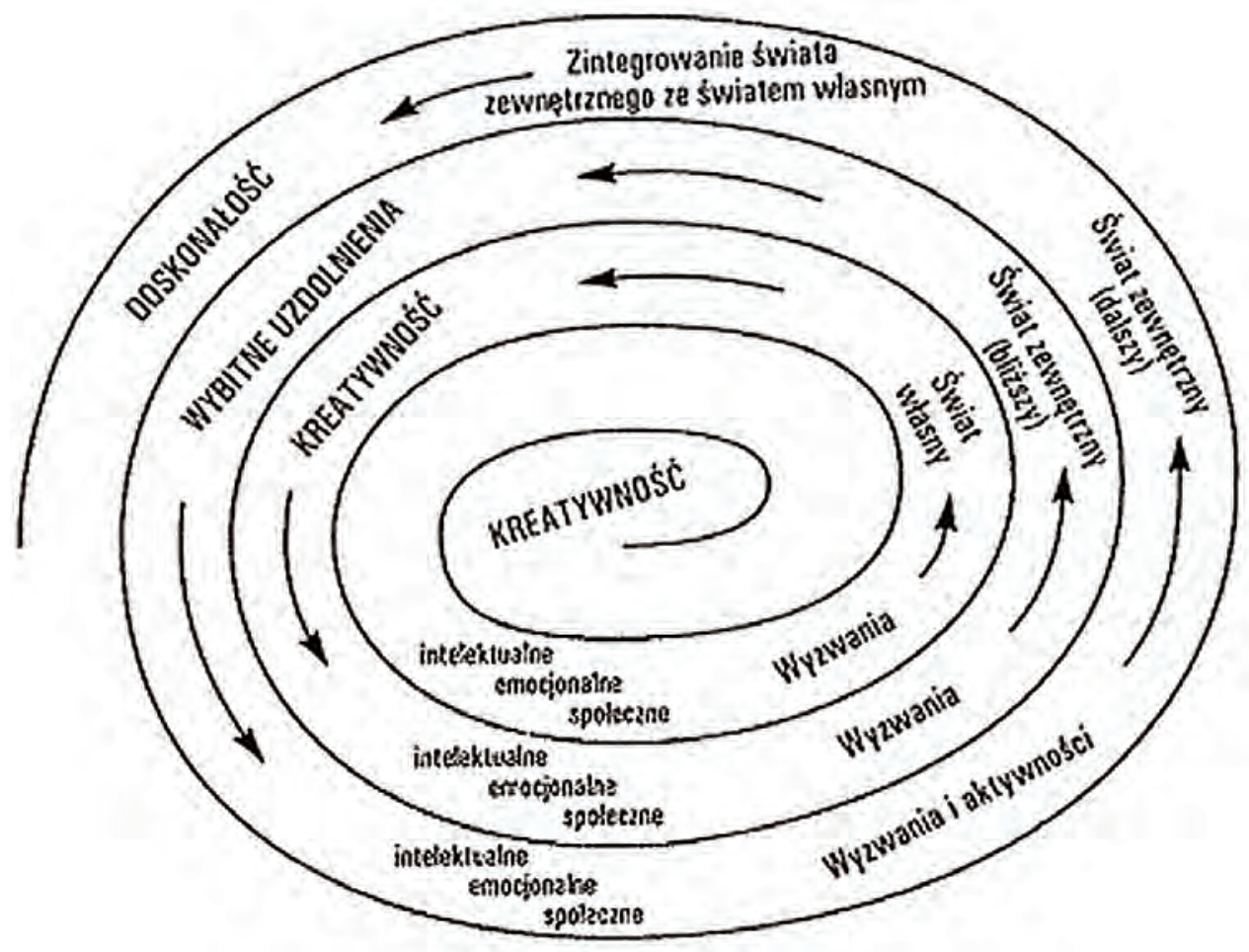

Rys. 3. Holistyczne podejście do talentu

Źródło: E. Landau, 2003, s. 198

Kolejnym humanistą poruszającym się w obrębie opisywanego zjawiska jest wspomniany już Françoys Gagné. Autor opracował Zróżnicowany Model Uzdolnień $i$ Talentu [The Differentiated Model of Giftedness and Talent], w którym przedstawia proces rozwoju i przekształcenia (transformacji) zdolności i uzdolnień w dojrzały talent. Pojmuje on talent w następujący sposób „Talent designates the superior mastery of systematically developed abilities (or skills) and knowledge in at least one field of human activity to a degree that places an individual within at least the upper $10 \%$ of age peers who are or have been active in that field or fields" [Talent oznacza ponadprzeciętne mistrzostwo systematycznie rozwijanych zdolności (lub sprawności) w przynajmniej jednej dziedzinie ludzkiego działania, i w stopniu, który plasuje jednostkę co najmniej w górnych 10\% wszystkich rówieśników aktywnych w danym momencie (lub w przeszłości) w danej dziedzinie, lub dziedzinach - tłum. aut.] (Gagné, 2004, s. 1).

Powyższa definicja odnosi się do modelu zaprezentowanego przez F. Gagné, w którym autor przedstawia różnicę pomiędzy pojęciem talentu (talent), a uzdolnieniem (giftedness). F. Gagné tak rozróżnia obydwa pojęcia: „Giftedness designates the possession and use of untrained and spontaneously expressed outstanding 
natural abilities or aptitudes (called gifts), in at least one ability domain, to a degree that places an individual at least among the top $10 \%$ of his or her age peers" [Osoby uzdolnione posiadają i spontanicznie manifestują niewyuczone, naturalne, ponadprzeciętne zdolności, potencjał zdolności i predyspozycje (zwane uzdolnieniami) w co najmniej jednym obszarze zdolności, i w stopniu plasującym je co najmniej w górnych 10\% wśród rówieśników - tłum. aut.] (Gagné, 2008, s. 1). „Talent refers to performance which is distinctly above average in one or more fields of human performance. [Talent odnosi się do ponadprzeciętnej sprawności w działaniu w jednej lub kilku dziedzinach działalności ludzkiej - tłum. aut.] (Gagné, 1985, s. 108). Model F. Gagné składa się z sześciu głównych elementów, które pomagają w zrozumieniu istoty talentu. W skład pierwszych trzech, zwanych rdzeniem rozwoju talentu, wchodzą:

- naturalne zdolności, uzdolnienia (intelektualne, twórcze, społeczne, percepcyjne oraz fizyczne związane z kontrolą motoryczną i ruchową), które pełnią funkcję bazy, fundamentalnych elementów dla tych umiejętności, które rozwiną się w kierunku określonego talentu. Naturalne zdolności można zaobserwować u dzieci w szkole oraz w domu;

- proces rozwojowy, który może być rozciągnięty w czasie na lata systematycznej nauki i ćwiczeń dzieli się na:

- aktywność związaną z różnymi programami nauczania, które dzięki odpowiedniej strukturze oferują różne możliwości wspierania i rozwoju zdolności i uzdolnień;

- postęp zaczyna się we wczesnych latach dzieciństwa i charakteryzuje się rozwojem zdolności, zaczynając od podstawowego poziomu, poprzez zaawansowany, biegły, kończąc na eksperckim. Wszystko zależy od tempa rozwoju i osiągnięć jednostki. Proces rozwoju może być przyspieszony, np. kiedy nauczyciel szybko zidentyfikuje uzdolnienia ucznia. Zła sytuacja osobista jednostki może mieć, z kolei, negatywny wpływ na rozwój zdolności, przyczyniając się do zahamowania procesu;

- inwestowanie w postaci czasu, energii oraz pieniędzy ma znaczący wpływ na efektywność procesu rozwojowego;

- wysoki poziom dobrze ukształtowanych umiejętności, które świadczą o pomyślnym procesie rozwoju talentu.

W dalszym ciągu F. Gagné opisuje katalizatory procesu rozwoju talentu, do których zalicza: czynniki intrapersonalne fizyczne (zdrowie, wygląd oraz niepełnosprawność) oraz psychiczne (temperament, osobowość, odporność), czynniki środowiskowe oraz zdarzenia losowe. Czynniki środowiskowe obejmują otoczenie (fizyczne, kulturowe, społeczne, rodzina) oraz rodziców, rodzinę, rówieśników i nauczycieli, którzy przyczyniają się do rozwoju uzdolnień. Bardzo ważne są również odpowiednio przygotowane programy nauczania w procesie edukacji szkolnej i pozaszkolnej. Przedstawione katalizatory mogą pełnić funkcję spiritus movens, ale mogą także przyczynić się do hamowania procesu rozwoju. 


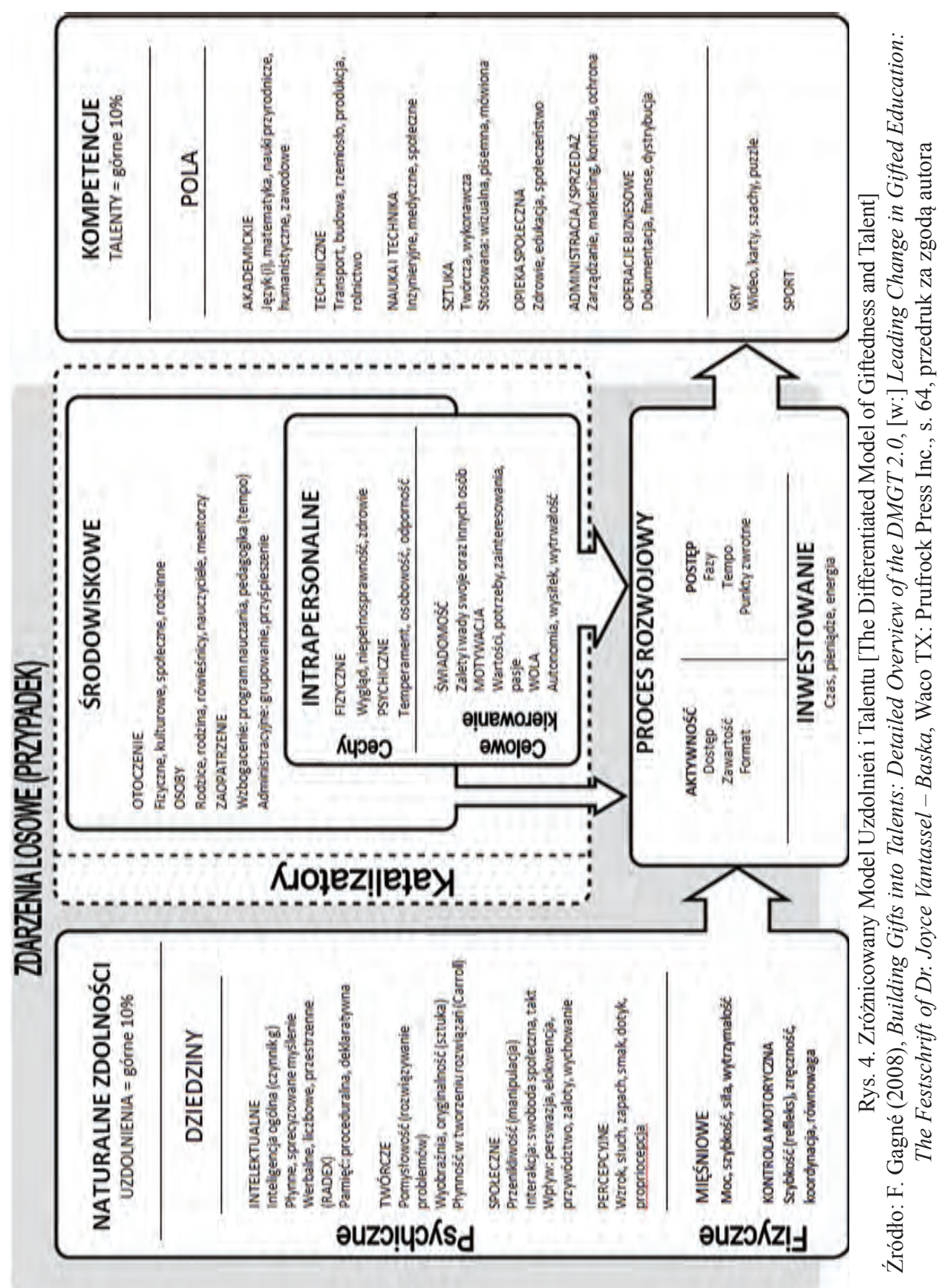


Elementem kluczowym w wyżej przedstawionym modelu jest różnica pomiędzy cechującym jednostkę dużym potencjałem (giftedness), a mistrzostwem systematycznie rozwijanych zdolności (talent). F. Gagné podkreśla również indywidualność osób uczących się (kultura, płeć itp.) oraz czynniki, które na nich wpływają, takie jak motywacja, zainteresowania, środowisko itp. Opisywany w tym modelu talent stopniowo wyłania się z przekształconych ponadprzeciętnych zdolności i zamienia w dobrze „oszlifowane” i systematycznie rozwijane umiejętności charakterystyczne dla poszczególnego obszaru ludzkiego działania. F. Gagné pokazuje niektóre z wielu obszarów talentów, w szczególności odnoszące się do młodzieży w wieku szkolnym. Naturalne zdolności mogą manifestować się na wielu płaszczyznach w zależności od obszaru aktywności prowadzonej przez jednostkę. Dobrym przykładem jest zręczność - naturalna fizyczna zdolność kształtowana jako indywidualna manualna umiejętność pianisty, malarza albo gracza. Podobnie inteligencja, jako naturalna zdolność, może być ukształtowana w narzędzie naukowca czy analityka finansowego.

Według Johna F. Feldhusena (1999, s. 623), talent to: ,superior aptitude or ability in any worthwhile line of human endeavor. It emerges early in childhood in a very general form such as verbal aptitude, mathematical skill, or artistic ability. It manifest itself in the child who speaks and reads early, who learns math more rapidly than other children, or who demonstrates leadership capability in first or second grade" [ponadprzęcietna predyspozycja lub sprawność w dowolnej dziedzinie wartościowego ludzkiego działania. Talent ukazuje się wcześnie w dzieciństwie w bardzo ogólnych formach, takich jak: zdolności werbalne, umiejętności matematyczne, albo zdolności artystyczne. Objawia się u dziecka, które wcześnie zaczyna mówić i czytać, które uczy się matematyki szybciej niż pozostałe dzieci, albo które odznacza się umiejętnościami przywódczymi w pierwszej, albo drugiej klasie - thum. aut.].

Zdaniem autora bazą talentu jest zainteresowanie i ciekawość. Autor uważa, że dzieci charakteryzujące się takimi cechami szybciej komunikują się ze światem, który je otacza. „Talent comes to fruition with the acquisition of a knowledge base and particular set of procedural skills. In itself, talent may simple denote functional proficiency in a particular career or occupational line of endeavor, but the proficiency paves the way to creative production" [Talent jest najbardziej owocny, gdy przyswojony zasób wiedzy połączy się z określonym zestawem sprawności proceduralnych. Talent sam w sobie oznaczać może jedynie wysoką sprawność funkcjonalną na danej ścieżce kariery czy też działania zawodowego, lecz ta właśnie wysoka sprawność umożliwia działanie kreatywne - tłum. aut.] (tamże, s. 624). J. F. Feldhusen podkreśla, że bardzo ważne jest, aby dziecko uświadomiło sobie i zrozumiało, czym jest jego talent we wczesnym dzieciństwie, po to, aby szkoła i rodzina mogły w odpowiednim czasie wspierać wzrost i rozwój talentu w określonej dziedzinie talentu. J. F. Feldhusen jest pionierem w zakresie identyfikacji i rozwoju talentów w edukacji i autorem modelu TIDE, który proponuje 
rozumienie talentu jako: „talent is a developmental phenomenon emerging out of general aptitude and into specific career-oriented abilities" [talent jest charakterystyczną cechą rozwoju osobowego, który wyłania się z ogólnej zdatności i zdolności ukierunkowanych na karierę zawodową - tłum. aut.] (Feldhusen, Jarwan, 1993, s. 234). Skłania się ku wspieraniu rozwoju talentu u każdego nastolatka zamiast koncentrowania się na niewielkim procencie uczniów, którzy zostali ocenieni ze względu na subiektywne kryterium, przypiętą metkę, szufladkującą ich na utalentowanych i zdolnych. Przyjmuje, że talent jest połączeniem zdolności, zdobytej wiedzy oraz pewnych cech osobowościowych. Ponadto wyodrębnia cztery obszary rozwoju talentów w szkołach:

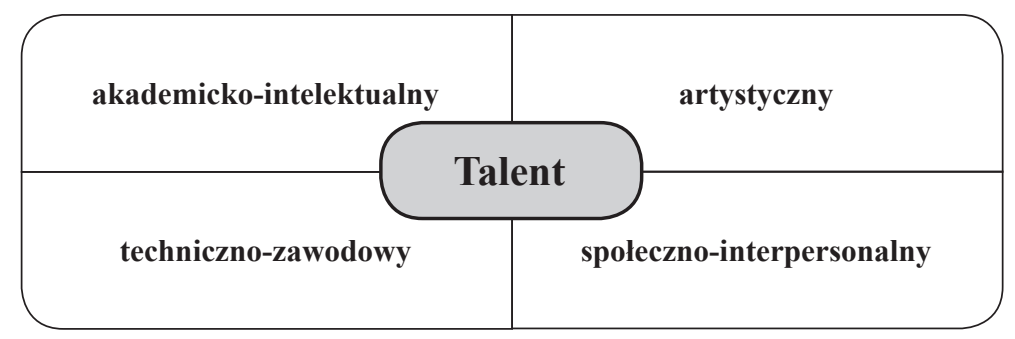

Rys. 5. Cztery rodzaje talentu wg J. F. Feldhusena Źródło: oprac. własne

Model TIDE koncentruje się na korzystaniu z różnych technik i narzędzi oceny (m.in. standardowych testów), które definiują profil ucznia, określając zarazem słabe i mocne strony talentu. Przygotowana w ten sposób ocena służy do opracowania indywidualnego planu rozwoju każdego ucznia.

Znaną badaczką istoty talentu jest Jane Piirto, która opracowała Piramidę Rozwoju Talentu - The Pyramid of Talent Development. Piramida J. Piirto zbudowana jest z pięciu poziomów: genetyczny (obszar genów), emocjonalny (w oparciu o osobowość), poznawczy (IQ), poziom talentu (specyficzne, wrodzone zdolności), poziom środowiskowy.

Aspekt środowiskowy zawiera pięć kategorii: dom, społeczność (wspólnota) i kultura, szkoła, płeć i czynnik losowy, które nad piramidą kształtem przypominają słońce. Aspekt genetyczny, o którym pisze J. Piirto, dotyczy dziedzictwa genetycznego, które wskazuje, że ludzie posiadają pewne predyspozycje. Aspekt emocjonalny dotyczy osobowości. Zdaniem autorki występują pewne wspólne cechy osobowości, charakterystyczne dla wszystkich twórców, którzy odnieśli sukces. W literaturze tematycznej różnych autorów znajdziemy duży zasób przymiotów przypisywanych osobom utalentowanym, między innymi: androgeniczność (androgyny), kreatywność (creativity), wyobraźnia (imagination), intuicja (intuition), przenikliwość (insight), otwartość (openness), postrzeganie (perceptivness), perfekcjonizm (perfectionism), zaangażowanie, oddanie w pracy w każdej dziedzinie, konsekwentny upór (persistence), odporność na trudy 
(resilience), skłonność do ryzyka (risk-taking), samodyscyplina (self-discipline), przekonanie o własnej skuteczności (self-efficacy), tolerancja dla wieloznaczności (tolerance for ambiguity), wolicjonalizm (volition). J. Piirto uważa, że wszystkie utalentowane osoby, które odnoszą sukces posiadają co najmniej jedną z wyżej wymienionych cech. Część z nich może być wrodzona albo rozwijana. Kolejny poziom piramidy dotyczy aspektu poznawczego (inteligencji). W opinii autorki podczas realizacji różnego rodzaju programów i badań osób utalentowanych w głównej mierze opieramy się na analizach testów psychologicznych - jednak zaznacza, że błędem byłoby opieranie się wyłącznie na wynikach testów w odniesieniu do całego człowieka (jego osobowości, cech charakteru, wykonywanego zawodu, pasji itp.). Podkreśla, że wynik testu ma jedynie opisowy charakter. Poziom inteligencji w piramidzie jest określany jako minimalne kryterium, zaczyn potrzebny do rozwoju talentu. Istnieje minimalny próg inteligencji, różny dla każdego z przejawów talentu. Autorka zaznacza przy tym, że dla rozwijania większości talentów nie jest bynajmniej konieczne posiadanie wysokiej bądź bardzo wysokiej inteligencji.

Ostatnim poziomem w piramidzie jest aspekt talentu. „The talent itself - inborn, innate, mysterious, is absolutely necessary" [Sam talent - wrodzony, przekazywany w genach, tajemniczy jest absolutnie niezbędny - tłum. aut.] (Piirto, 1999, s. 5). Autorka uważa ponadto, że większość talentów jest rozpoznawalna poprzez pewne przewidywalne zachowania (predictive behaviors) - np. dziecko, które bardzo dobrze rysuje jest typowane do klasy o profilu artystycznym.

Na szczycie piramidy J. Piirto umieściła aspekt powołania. Wiele osób posiada więcej niż jeden talent, ale zastanawia się, co z nim zrobić, tym samym nie potrafi go wykorzystać. Ten aspekt nazywa się powołaniem (vocational passion the thorn), ponieważ nęka, daje się we znaki właścicielowi, dopóki nie zdobędzie przewagi, nie pobudzi go do działania dla rozwoju talentu. Powołanie jest „,cierniem" motywującym do działania, sprawia, że osoba czuje potrzebę wykorzystania swojego talentu. Autorka piramidy wspomina również, że każda dziedzina rozwija talent $\mathrm{w}$ inny sposób. W naukowym i akademickim obszarze talent jest rozwijany w ramach formalnej edukacji.

Należy tu zauważyć, że powyższe rozważania Piirto, choć używa ona terminu „talent”, w dużej mierze odnoszą się do pojęcia opisywanego przez innych autorów jako uzdolnienia czy „dar”. J. Piirto również opisuje pojęcie zwane wielopotencjałem (multipotentiality). Dotyczy ono osób posiadających więcej niż jeden talent. Ludzie $\mathrm{z}$ wielopotencjałem powinni umieć dostrzec odczuwane przez siebie pozytywne wyzwanie. Stan zamyślenia, zadumy wspólny dla każdego kreatywnego procesu rozwoju talentu zaczęto niedawno nazywać „przepływem” (flow). Termin ten, przypadkowo wymyślony przez psychologa Mihalyi Csikszentmihalyi (1990), odnosi się do sytuacji człowieka zaangażowanego w aktywność, która jest jednocześnie wyzwaniem i nagrodą. 
Ostatnie ujęcie w piramidzie dotyczy czynnika środowiskowego, który obejmuje pięć elementów:

- dom i rodzina - są kluczowe, ponieważ talent wydaje się być wspierany przez środowisko rodzinne. Jest to widoczne w takich rodzinach, w których talent dziecka jest pielęgnowany i wspierany przez rodziców;

- wspólnota i kultura - wymiar społeczny i kulturowy jest bardzo ważny. Psychologowie społeczni opisali efekt ducha czasu (the Zeitgeist), który decyduje o tym, czy jakiś pomysł, patent, innowacja zostaną zauważone i docenione czy nie;

- szkoła - kategoria szkoły jest bardzo pomocna. Szkoła ma za zadanie pomóc tym dzieciom, które nie miały wystarczająco dużo szczęścia, aby urodzić się $\mathrm{w}$ środowis $=\mathrm{ku}$, które będzie pielęgnowało ich ponadprzeciętny potencjał;

- płeć - ten aspekt jest bardzo ważnym czynnikiem środowiskowym pomimo wielu wrodzonych różnic płciowych. Zdaniem autorki powinniśmy przyjrzeć się rozwojowi talentu względem płci;

- czynnik losowy może być również bardzo istotny. Zwykły przypadek urodzenia może mieć znaczenie podczas rozwoju kariery, tak jak zostało to zaznaczone na rysunku 6. w postaci słońc.

Wyżej wymienione elementy narysowane zostały nad piramidą w kształcie słońc. Każde „słońce” oświetla niejako talent, spełniając swoją rolę. Czynnik środowiskowy jest inhibitorem albo stymulatorem rozwoju talentu. Przy czym trzeba podkreślić, że „słońce” szkoły pełni funkcję pomocnej dłoni w momencie, w którym inne słońca zgasną.

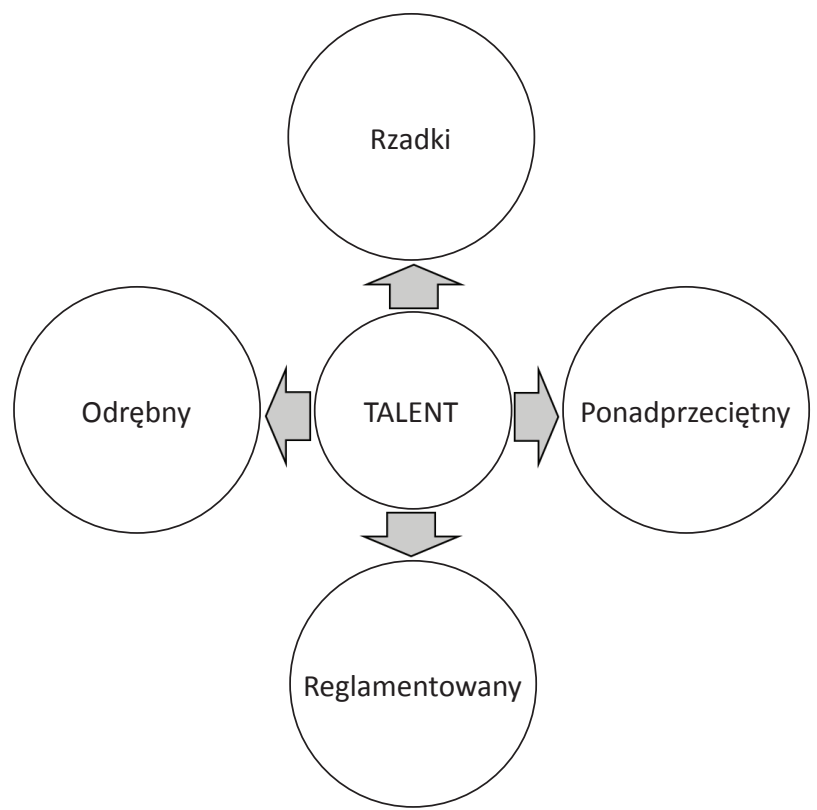

Rys. 6. Cztery rodzaje talentu w ujęciu A. J. Tannenbauma Źródło: oprac. własne 
Wartym przedstawienia wydaje się też model talentu A. J. Tannenbauma. W opinii badacza rozwinięty talent występuje tylko u osób dorosłych. Autor proponuje cztery rodzaje talentów.

Talenty rzadkie (scarcity talents), jak sama nazwa wskazuje, mają unikatowy charakter i są sporadycznie spotykane w społeczeństwie. Ponadprzeciętne talenty (surplus talents) nie są niezbędne do życia (egzystencji) i obejmują jednostki, które wnoszą ogromny wkład w sztukę, literaturę, muzykę i filozofię. Ludzie o ponadprzeciętnym talencie są postrzegani jako unikatowe jednostki, zdolne wzbogacić i upiększyć świat. Jednak ze względu na niepowtarzalność tych talentów trwałość i kontynuacja procesu nie może być zagwarantowana. Talenty reglamentowane (quota talents) to te, które wymagają wysokich umiejętności, by móc zaowocować dobrami potrzebnymi społeczeństwu. Naród potrzebuje tego typu talentów w ograniczonym zakresie. Szkoły wyczulone na potrzeby społeczeństwa kreują, modelują określone talenty (techniczne, nabyte). Ostatnią kategorią są talenty odrębne (anomalous talents). Kategoria ta zawiera specyficzne, wyizolowane, nietypowe, rzadko spotykane zdolności, takie jak szybkie czytanie lub ponadprzeciętna zdolność zapamiętywania. Takie talenty wprawiają w zdumienie, ale mogą również służyć praktycznym celom, chociaż są postrzegane raczej jako przykłady niepowtarzalnych zdolności niż jako przejaw geniuszu.

Można zaryzykować stwierdzenie, że ilu jest autorów, tyle jest definicji talentu. Pocieszające jest to, że można znaleźć wspólny mianownik dla wszystkich teorii, mianowicie, że talent jest wypadkową systematycznie rozwijanych umiejętności zależnych od wielu czynników, które mogą być inhibitorami albo stymulatorami jego rozwoju.

\section{Percepcja talentu - relacja z badań własnych}

Poniżej przedstawiam wyniki badań dotyczące sposobu percepcji pojęcia talent przez uczestników programu telewizyjnego Mam talent ${ }^{10}$, jego producentkę oraz ekspertów - 18 uczestników Laboratorium Treningu Twórczości w Poznaniu zorganizowanego przez Polskie Stowarzyszenie Kreatywności ${ }^{11}$. Warsztaty organizowane są przez Polskie Stowarzyszenie Kreatywności skupiające wszystkie osoby bezpośrednio związane z twórczością, zdolnościami specjalnymi oraz talentem, co sprawia, że stanowią doskonałe źródło opinii na temat badanych zjawisk.

${ }^{10}$ Program America's Got Talent to amerykańska wersja typu talent show (polskiego Mam talent), która widnieje na ekranach telewizorów już od 2006 r. Jest to pierwsza na świecie odsłona tego programu. Mam Talent jest emitowany przez telewizyjną stację TVN, największą prywatną grupę medialną w Polsce.

${ }^{11}$ Laboratorium Twórczości jest to jedna z form edukacyjnych, cyklicznie organizowana przez Polskie Laboratorium twórczości, patrz www.psk.pl 
W badaniach wykorzystałam metodę sondażu diagnostycznego, w którym posłużyłam się techniką ankiety i wywiadu. W ramach swojego projektu badawczego podjęłam próbę wskazania problemów związanych z rozumieniem pojęcia zdolno$\dot{s} c i$ i talent przez respondentów. Przebadanych przeze mnie respondentów należy podzielić na cztery podgrupy: 104 uczestników castingów programu Mam Talent, 10 osób z ekipy pracującej przy produkcji programu, producentka programu Mam Talent oraz uczestnicy Laboratorium Treningu Twórczości PSK jako swoiści eksperci. Największą z nich jest grupa uczestników castingów do programu.

Najpopularniejszą dziedziną zdolności prezentowanych przez uczestników programu był taniec $(33,66 \%)$, a następnie inne rodzaje zdolności $(25,96 \%)$, wśród których można znaleźć, takie jak: fireshow ${ }^{12}$, akrobacje piłkarskie, flair ${ }^{13}$, gra na garnkach, perkusji, skrzypcach, pianinie, gitarze, żonglerka, iluzja, dublerstwo, capoeira ${ }^{14}$ połączona $\mathrm{z}$ grą na berimbau ${ }^{15}$, atabaque ${ }^{16} \mathrm{i}$ pandeiro ${ }^{17}$, pantomima ${ }^{18}$, gra na harmonijce ustnej, mandolinie ${ }^{19}$, listku, tricki sztuk walk, show lalkarski, show z bańkami.

Ważnym elementem projektu było zbadanie rozumienia pojęcia talentu przez respondentów w kontekście trzech $\operatorname{cech}^{20}$ odróżniających osoby utalentowane od przeciętnych. Ponadto, powiązałam cechy podane przez respondentów ze źródłem talentu rozumianym jako cecha wrodzona albo wyuczona. Odpowiedzi przedstawia tabela 1:

${ }^{12}$ Fireshow to taniec, pokaz teatralny z użyciem żywego ognia.

${ }^{13}$ Flair to pokaz barmański z wykorzystaniem sprzętu barmańskiego (butelki z alkoholem, shakery, lód), w którym końcowym efektem jest koktajl. Tego typu show w stylu flair można zobaczyć w filmie Koktajl w reżyserii Rogera Donaldsona.

${ }^{14}$ Capoeira to synteza takich dziedzin jak taniec, sztuka walki, a także śpiew i gra na instrumentach (http://www.capoeira.com.pl/index.php?option=com_content\&task=view\&id=20\&Itemid=24). Wywodzi się z afrykańskiej i brazylijskiej tradycji sztuk walki. Więcej na ten temat można przeczytać na stronie http://www.capoeira.com.pl/

${ }^{15}$ Berimbau to tradycyjny instrument składający się z jednej struny, który jest bardzo powszechny w północno-wschodniej Brazylii, wykorzystywany jako symbol w capoeira.

${ }^{16}$ Atabaque jest bębnem, który używany byt początkowo w afro-brazylijskich obrzędach i rytuatach, a następnie stat się instrumentem w muzyce Capoeira. Jest to duży bęben ustawiany zwykle na stojaku i uderzany rękami (http://www.siemianowice.capoeira.pl/index.php?option=com_conten t\&task= view\&id=64\&Itemid=76).

${ }^{17}$ Pandeiro to odpowiednik europejskiego tamburynu. Pandeiro różni się jednak od tamburynu tym, że na obręcz napięta jest skóra. Dźwięki powstaja poprzez uderzanie w skórę lub potrzasanie calym instrumentem (http://www.siemianowice.capoeira.pl/index.php?option=com_content\&task= view\&id=64\&Itemid $=76$ ).

${ }^{18}$ Pantomima to minodram, pokrewne baletowi przedstawienie sceniczne, którego treść wyrażaja aktorzy za pomoca gry twarzy i gestów (http://www.slownik-online.pl/kopalinski/35AC0ABB 43AF3F30C1256576006E D 879.php).

${ }^{19}$ Mandolina z języka greckiego pandoúra to mała mandola o korpusie rezonansowym bardzo wypuktym, ksztattu migdała, instrument solowy albo zespołowy, zwłaszcza amatorski (http://www. slownik -online.pl/kopalinski/AB1FEBA109411CABC12565D9004A02D1.php).

${ }^{20}$ Podane cechy przytaczam dosłownie. 
Cechy różniące osoby utalentowane od przeciętnych

\begin{tabular}{|c|c|c|c|c|c|}
\hline & Cechy wrodzone & $\begin{array}{l}\text { Cechy wrodzone } \\
\text { i kształcone }\end{array}$ & $\begin{array}{l}\text { Przede wszyst- } \\
\text { kim nabyte }\end{array}$ & Tylko nabyte & Inne \\
\hline $\begin{array}{c}\text { Wartość } \\
\text { W \% }\end{array}$ & $37 \%$ & $45 \%$ & $8 \%$ & $10 \%$ & \\
\hline \multirow{18}{*}{ 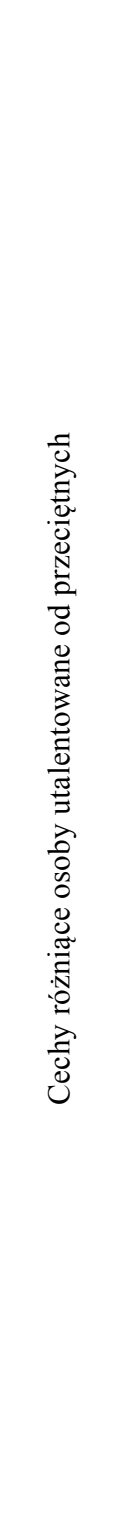 } & pracowitość & otwartość & asertywność & $\begin{array}{l}\text { systematycz- } \\
\text { ność }\end{array}$ & $\begin{array}{l}\text { nie ma } \\
\text { takich }\end{array}$ \\
\hline & $\begin{array}{l}\text { większa wrażli- } \\
\text { wość }\end{array}$ & pomysłowość & większa wiedza & $\begin{array}{l}\text { cierpliwe dąże- } \\
\text { nie do celu }\end{array}$ & $\begin{array}{l}\text { są sobie } \\
\text { równi }\end{array}$ \\
\hline & konkretność & kreatywność & $\begin{array}{l}\text { sprawność } \\
\text { fizyczna }\end{array}$ & $\begin{array}{l}\text { uroda i boga- } \\
\text { ctwo }\end{array}$ & \\
\hline & charyzma & przebojowość & $\begin{array}{l}\text { większe poczu- } \\
\text { cie własnej } \\
\text { wartości }\end{array}$ & $\begin{array}{l}\text { praca warszta- } \\
\text { towa }\end{array}$ & \\
\hline & osobowość & skromność & $\begin{array}{l}\text { świadomość } \\
\text { talentu }\end{array}$ & trening & \\
\hline & $\begin{array}{l}\text { sposób postrze- } \\
\text { gania świata }\end{array}$ & odwaga & & ciężka praca & \\
\hline & $\begin{array}{l}\text { specyficzne } \\
\text { zdolności }\end{array}$ & rozbawianie ludzi & & & \\
\hline & dobra percepcja & $\begin{array}{l}\text { wyróżnianie się } \\
\text { spośród tłumu }\end{array}$ & & & \\
\hline & $\begin{array}{l}\text { szybsze przyswa- } \\
\text { janie informacji }\end{array}$ & szacunek dla ludzi & & & \\
\hline & $\begin{array}{l}\text { dar przekony- } \\
\text { wania }\end{array}$ & poczucie humoru & & & \\
\hline & ambicja & wiara w siebie & & & \\
\hline & inteligencja & $\begin{array}{l}\text { brak zarozumial- } \\
\text { stwa i pychy }\end{array}$ & & & \\
\hline & $\begin{array}{l}\text { nieskrępowana } \\
\text { wyobraźnia }\end{array}$ & wytrwałość & & & \\
\hline & uzdolnienia & dynamika & & & \\
\hline & $\begin{array}{l}\text { dar, inny dla } \\
\text { każdego czło- } \\
\text { wieka }\end{array}$ & odporność na stres & & & \\
\hline & uduchowienie & oryginalność & & & \\
\hline & potencjał & zapamiętywalność & & & \\
\hline & upór & $\begin{array}{l}\text { robienie czegoś } \\
\text { lepiej niż inni }\end{array}$ & & & \\
\hline
\end{tabular}


Tab. 1 (cd.)

\begin{tabular}{|c|c|c|c|c|c|}
\hline & Cechy wrodzone & $\begin{array}{l}\text { Cechy wrodzone } \\
\text { i kształcone }\end{array}$ & $\begin{array}{c}\text { Przede wszyst- } \\
\text { kim nabyte }\end{array}$ & Tylko nabyte & Inne \\
\hline \multirow{10}{*}{ 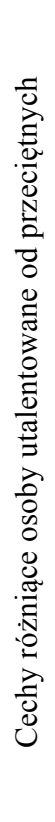 } & chęć rozwoju & nietuzinkowość & & & \\
\hline & osobowość & wyjątkowość & & & \\
\hline & pasja & pokora & & & \\
\hline & $\begin{array}{l}\text { wielkie zaanga- } \\
\text { żowanie }\end{array}$ & pewność siebie & & & \\
\hline & pasja & pokora & & & \\
\hline & & narcyzm & & & \\
\hline & & $\begin{array}{l}\text { umiejętność znale- } \\
\text { zienia się w każdej } \\
\text { sytuacji }\end{array}$ & & & \\
\hline & & $\begin{array}{l}\text { umiejętność za- } \\
\text { chwycenia innych }\end{array}$ & & & \\
\hline & & $\begin{array}{l}\text { dojrzałość psychi- } \\
\text { czna, społeczna } \\
\text { i intelektualna }\end{array}$ & & & \\
\hline & & $\begin{array}{l}\text { dokładność, per- } \\
\text { fekcjonizm }\end{array}$ & & & \\
\hline
\end{tabular}

Źródło: badania własne.

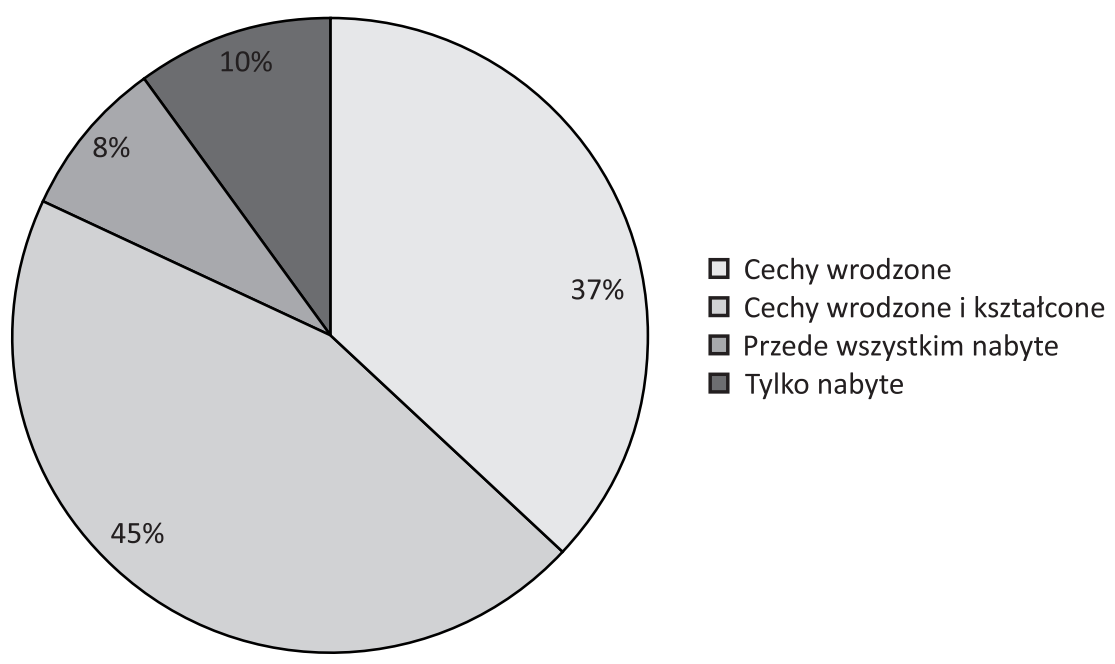

Wykres 1. Źródło talentu

Źródło: badania własne 
Tabela zawiera dwa typy informacji. Uwzględnia cechy, które odróżniają osoby utalentowane od tych przeciętnych, a zarazem pokazuje wartość procentową dotyczącą źródła talentu. W pytaniu otwartym respondenci byli proszeni o podanie trzech cech, które według nich są przypisane osobom utalentowanym. W przeważającej części ankietowani twierdzili, że najważniejszymi cechami są: uzdolnienia, specyficzne zdolności, pracowitość, osobowość, kreatywność, oryginalność, wytrwałość, dążenie do celu i rozwoju, wyjątkowość, pasja, wyższa inteligencja, większa percepcja i dojrzałość psychiczna oraz intelektualna, a także wielkie zaangażowanie. Dla porównania warto zestawić odpowiedzi ekspertów, dla których najważniejszymi cechami osób utalentowanych są: pomysłowość, indywidualność, niezależność w myśleniu i działaniu, ponadprzeciętność, wytrwałość, uzdolnienia specjalne, wrażliwość, motywacja, ukierunkowanie, pracowitość, twórczość, bardzo dobra pamięć, pasja, dążenie do rozwoju, specjalne zdolności intelektualne i kierunkowe oraz większa chęć do działania. Punktem spornym był poziom inteligencji, ponieważ część ekspertów odpowiedziała, że osoby utalentowane muszą mieć wyższy poziom inteligencji niż przeciętny, podczas gdy reszta specjalistów uznała, że bardzo często wyższy poziom inteligencji nie gra żadnej roli. Wiesława Limont, jako ekspert zajmujący się zdolnościami i uzdolnieniami na co dzień, odpowiedziała, że najistotniejszymi cechami są zdolności ogólne i/lub kierunkowe, zdolności twórcze oraz odpowiednie cechy osobowości w tym motywacja samoistna.

W kolejnym pytaniu ankietowani przedstawili opinie dotyczące tego, czy według nich talentu można się nauczyć, czy trzeba się z nim urodzić?

Zanalizowałam pozyskany materiał przez przypisanie źródła do każdej cechy. Tabelka przedstawia, która z cech jest tylko wrodzona, wrodzona i kształtowana, przede wszystkim nabyta, tylko i wyłącznie nabyta. Można zaobserwować wyraźną różnicę dotyczącą korzeni talentu.

Łącznie 82\% ankietowanych było zdania, że talent jest po części wrodzony i kształtowany. Zaledwie $18 \%$ badanych uważało, że talent jest przede wszystkim nabyty albo tylko i wyłącznie nabyty bez posiadania żadnych zdolności wrodzonych. Uzasadniając wyżej wymienioną statystykę, warto przytoczyć niektóre ciekawsze wypowiedzi ${ }^{21}$ respondentów, którzy w następujący sposób argumentowali swoje odpowiedzi pisząc, że:

- Talent to w niewielkim stopniu cecha nabyta, która trzeba rozwinać poprzez prace, trening - to jedyna droga do odkrycia talentu.

- Myślę, że z talentem czlowiek się rodzi, ale musi té̇ ciężko nad nim pracować by lśnit jak oszlifowany diament.

- Myślę, że trzeba się z nim urodzić, ale jednocześnie ciagle szlifować.

- Może być wrodzony i nabyty.

- Wszystko jest do nauczenia, aczkolwiek trzeba mieć w sobie pewne cechy.

- $20 \%$ to talent, pozostate $80 \%$ to ciężka praca.

${ }^{21}$ Odpowiedzi przytaczam dosłownie. 
- Można się go nauczyć - choć istota tej nauki jest wydobywanie na powierzchnię glęboko ukrytych, wybitnych predyspozycji.

- Z talentem można się urodzić, ale trzeba go szlifować.

- Talent jest wypadkowa doświadczeń i wychowania, raczej się nie da go świadomie wyksztatcić, może się tylko ujawnić.

- Można wyrobić w sobie pewien warsztat, ale potrzebna jest wyobraźnia i kreatywność i pewność siebie.

- Całkiem wysoko można zajść przez ciężka prace, talent wrodzony to ułatwia, jednak nie jest to niezbędne do osiagnięcia sukcesu.

Eksperci biorący udział w badaniu w przeważającej części zgadzają się z opinią respondentów, którzy uznali, że talent jest wrodzony i kształtowany. Wśród odpowiedzi profesjonalistów można znaleźć takie wypowiedzi, jak np.:

- Uważam, że trzeba mieć wrodzone predyspozycje, które należy rozwinać.

- Talent to predyspozycja i trzeba nauczyć sie ja ksztatcić $i$ wykorzystać.

- Talent uzewnętrznia się czasami samoistnie lub przez osobę trzecia.

- Zadatki zdolności kierunkowych sa wrodzone, ale potrzeba pracy, żeby talent sie ,,wyklut” i rozwinat.

- Talent musi mieć „,szansę” ujawnienia się, a więc splot okoliczności może pomóc go wydobyć, a nastęnie różne czynniki moga być jego stymulatorami bądź inhibitorami.

- Talent jest wrodzony + wyuczony (odnaleziony w sobie).

- Jest wrodzony + wyuczony, talent to ponadprzeciętne zdolności intelektualne lub kierunkowe (artystyczne, przywódcze, sportowe itd.), wysoka twórczość, wysokie zaangażowanie. Jest to w skrócie triadowy model zdolności J. Renzullego, ale catkowicie się z nim zgadzam.

- Uzdolnienia wrodzone lub nabyte $w$ danej dziedzinie.

- Wrodzony jest potencjat zwiazany z baza biologiczna jednostki. Osoby zdolne rozwijaja posiadany potencjat w korzystnym dla nich środowisku, pod wpływem oddziaływań edukacyjnych $i$ wielu innych czynników trudnych do przewidzenia. Przypadek także ma duże znaczenie.

Według producentki programu Mam talent - ,talent to połączenie iskry bożej, to co człowiek ma w genach [...] zdolność do czegoś, bardzo dużą pracę, którą musi wykonać, aby tą iskrę rozbudzić". Według tej respondentki talentu nie można się nauczyć. W swobodnej rozmowie wyraziła zadowolenie z tego, że w głosowaniach ludzie w Polsce nie popełniają błędów i wybierają ,prawdziwe talenty". Zarówno I, jak i II edycja to potwierdza. Uważa, że ludzie potrafią odróżnić przeciętność od czegoś nadzwyczajnego. W odniesieniu do problemu odkrywania i promowania osób utalentowanych w Polsce, w opinii producentki w większości sytuacji potrzebne jest czyjeś zainteresowanie, czyli głównie tego pierwszego nauczyciela, mentora, który odkryje ten talent. Porównując międzynarodową promocję talentów, Polska wypada dosyć słabo na tle innych krajów. 
Według producentki Mam talent w Polsce sposób myślenia o talencie jest jeszcze mało perspektywiczny, ponieważ np. wytwórnie płytowe nie chcą wcale inwestować w nowe osoby, w przeciwieństwie do innych krajów, w których prężnie działają różne firmy zajmujące się wyszukiwaniem utalentowanych ludzi.

Jednoznaczne określenie, czy zdefiniowanie talentu i znalezienie jego źródła było dla respondentów (ekspertów, uczestników castingu łącznie z producentką programu) trudnym zadaniem.

W pytaniu końcowym zapytałam ekspertów o ich wyobrażenia na temat odkrywania i promowania ludzi utalentowanych w Polsce. Poniżej przedstawiam ich odpowiedzi ${ }^{22}$ :

\section{Ankieta pierwsza}

Praca z uczniem zdolnym w szkołach (SP, G, LO) to fikcja. Trochę promocji na uczelniach technicznych, bo efekt może być szybko materialny.

\section{Ankieta druga}

Wydaje mi się, że szkoła, która powinna być ,wylęgarnia” talentów nie spetnia swojego zadania. Doceniane sa najcześsiej zdolności do uczenia się poszczególnych przedmiotów, a pozostałe zaniedbywane. Brak odpowiednich ogólnodostępnych zajęć, które rzeczywiście rozwijatyby talenty, a nie byty ,douczkami” pozalekcyjnymi, brak świadomości rodziców, którzy często blokuja dziecko, sami wybieraja zajęcia dodatkowe, czasem niezgodne z zainteresowaniami i potrzebami dziecka.

Nie wiem, czy instytucje (fundacje, stowarzyszenia) zajmujace się promowaniem i rozwijaniem talentów działają wystarczająco prężnie, ale wydaje mi się, że jest ich za mało.

\section{Ankieta trzecia}

To zależy od środowiska, $w$ którym ten proces się odbywa. Raz jest to show telewizyjne, innym razem zacisze laboratorium. Często jednak temu towarzyszy zawiść tzw. postronnych widzów - osób nie zwiąanych z tematem. Przykład - np. Informacja o odkryciu czy jakimś wybitnym osiagnięciu naukowym czy medialnym opublikowana np. na portalu gazeta.pl i od razu w komentarzach setki zgryźliwych uwag. W Polsce niestety kreowane jest ,s'redniactwo”, wybicie się nie jest mile widziane.

\section{Ankieta czwarta}

Moim zdaniem osoby utalentowane nie zostaja odkryte. Polska szkoła nie stawia na talent, indywidualność, lecz na odklepywanie zadanych regutek $i$ wstawianie w szereg. Zazwyczaj dziecko zmuszone jest skupiać się na przedmiotach, z którymi kiepsko sobie radzi (aby podwyższyć średnia), natomiast rzadziej rozwija się zainteresowania. Kompletnie o rozwijaniu zdolności nie ma mowy w większości matych szkót w niewielkich miejscowościach. Promuje się zazwyczaj osoby medialne, potrafiące się sprzedać i te, które klient chętnie kupi, a nie faktycznie zdolne. Chyba, że ten zdolny ma wyjątkowe szczęście...

${ }^{22}$ Odpowiedzi przytaczam dosłownie. 


\section{Ankieta piąta}

Moja opinia jest zła. Tegoroczna akcja komuś pewno pomoże i to dobrze, ale nie zmieni struktur społecznych i świadomości. Do tego potrzebna jest świadoma i głęboka wola polityczna, albo szeroki oddolny ruch społeczny. Tego nie ma. Gdyby się zaczęto, to bytby cud. Tymczasem madrzy się chowaja a rzadza przeciętni. Sa jednak dziedziny i miejsca, $w$ których promuje się talenty $n p$. w informatyce Profesorowie Jan Madey i Krzysztof Diks. Warto wiedzieć, jak oni to robia, bo to działa.

\section{Ankieta szósta}

Temat rzeka - wciąż zbyt mało placówek, miejsc dla rozwoju talentów.

\section{Ankieta siódma}

W Polsce nie ceni się ludzi z talentem. Sami przedzieraja się przez dżungle niechęci, nieakceptacji ich niższości, ich dociekliwości, indywidualności. Szczególnie zasmucające to jest w szkołach, na wszystkich poziomach edukacji - tam talenty bardzo często bezpowrotnie ,przepadaja”.

\section{Ankieta ósma}

Niestety nie ma jednolitej strategii wspierania rozwoju utalentowanych dzieci $w$ szkole (zbyt słabo przygotowani sa nauczyciele, nadal góruje uśrednianie i dażenie do wysokiej średniej ,odtwórczej” na testach).

\section{Ankieta dziewiąta}

Niestety brakuje zorganizowanych form pomocy osobom zdolnym, utalentowanym. Wszystkie te programy rozrywkowe sa tylko sposobem na przyciagnięcie uwagi, a nie promowaniu talentów.

\section{Ankieta dziesiąta}

Najpierw się ich nie promuje, nie pomaga, nie odkrywa, a gdy mają szczęście ujawnić swoja ponadprzeciętność to dopiero następuje promocja.

Przedstawione powyżej wybrane poglądy i przekonania wypowiedziane były przez pedagogów, psychologów, trenerów i nauczycieli. Wiesława Limont zapytana o swoje spojrzenie na temat odkrywania ludzi utalentowanych w Polsce odpowiedziała, że nie istnieje w Polsce odpowiedni system identyfikacji zdolności, kształcenia i wzmacniania ich działania.

Biorąc pod uwagę powyższe wypowiedzi, można wysnuć wniosek, że mechanizm odkrywania i wspierania talentów w Polsce funkcjonuje na bardzo słabym poziomie (zob. badania Dyrdy, 2012; artykuł K. J. Szmidta w tym tomie). Wciąż jeszcze pozostaje wiele do zrobienia, aby ów system mógł zacząć sprawnie działać, spełniając swoją podstawową rolę autentycznego wsparcia, kształcenia i wzmacniania zdolności i uzdolnien. 


\section{Podsumowanie i wnioski}

W podsumowaniu zestawiłam pojęcie talentu w sieci semantycznej. Pośrodku sieci umieściłam kluczowe pojęcie talentu, od którego rozgałęziają się opinie różnych grup badanych: ekspertów, uczestników programu Mam talent, producentki, a ponadto uzupełniłam dodatkowo definicją słownikową i naukową.

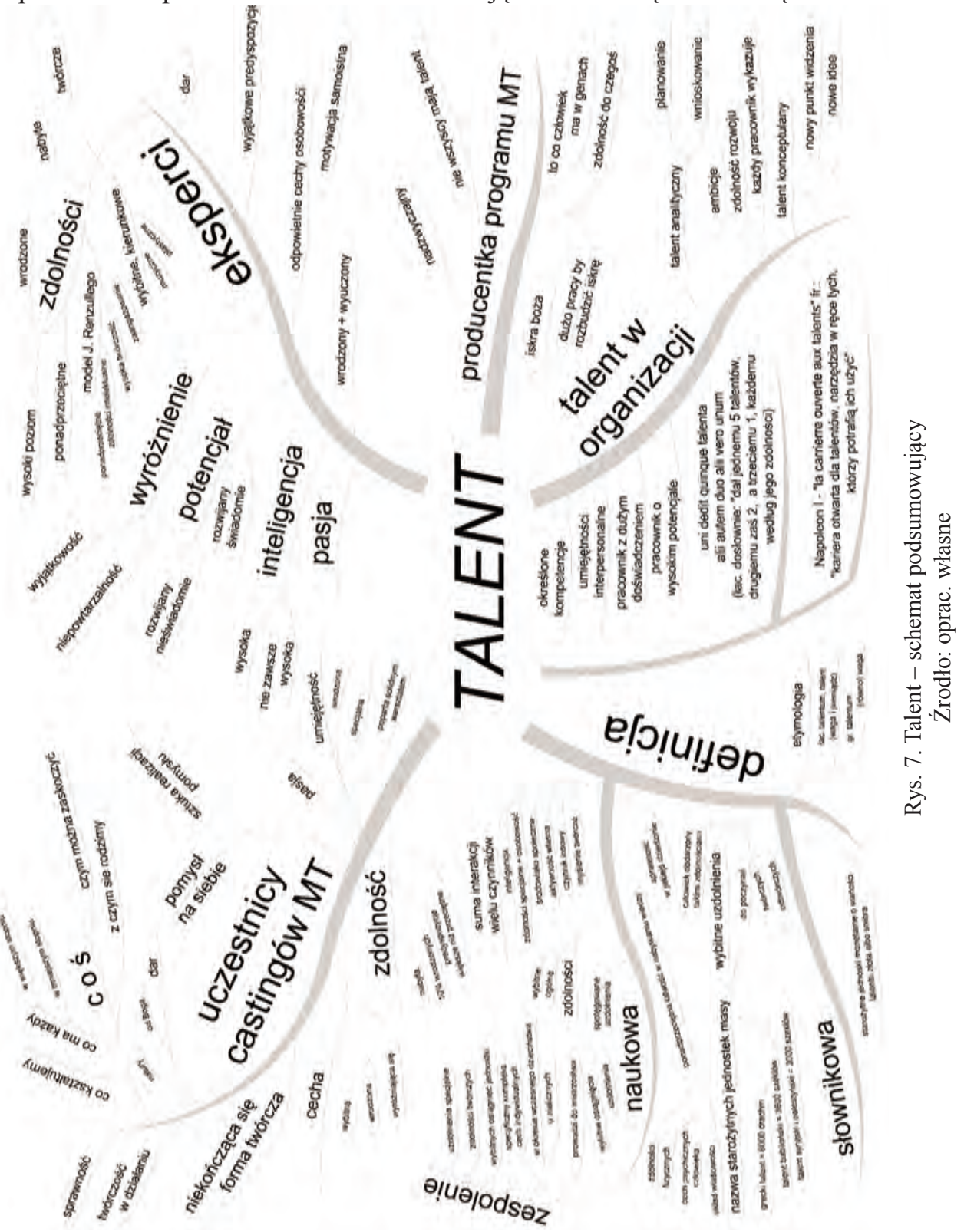


Przygotowany przeze mnie schemat pola semantycznego pozwala na ukazanie zjawiska talentu poprzez asocjacje definicji potocznej według niektórych respondentów oraz definicji naukowej. Taki sposób przedstawienia badanego terminu pozwala na zajrzenie w głąb pojęcia i ukazuje ścieżki skojarzeń. Sieć semantyczna ujawnia zarówno potoczną wiedzę na temat talentu, która występuje w powszechnym użyciu i jest wypadkową doświadczeń i przekonań większości respondentów, jak i naukową, którą konstruują specjaliści, eksperci z konkretnej dziedziny (psychologii, pedagogiki, socjologii). Odpowiada również na pytanie: jak respondenci rozumieją wybrane zjawisko, jakim jest talent? Ponadto, weryfikuje wyniki badawcze.

Schemat przedstawia pole semantyczne, będące zbiorem wszystkich możliwych znaczeń (ujawnionych w badaniach) dla kluczowego pojęcia, włączając w to znaczenia przeszłe, archaiczne (np. starożytne jednostki monetarne czy w przypowieści biblijnej jednostki wagi) oraz współczesne, funkcjonujące obecnie w świadomości społecznej. Graficzne przedstawienie talentu umożliwiło przegląd moich dotychczasowych badań nad percepcją talentu i zdolności w oparciu, między innymi, o program telewizyjny Mam talent.

Definicja naukowa zbudowana przez specjalistów z dziedziny talentu oraz potoczna nie wykazują wielu istotnych różnic. Zarówno badani przeze mnie eksperci, jak i producenci programu telewizyjnego, a także wspomniani w tekście teoretycy traktują talent jako wysoki poziom posiadanych zdolności, uzdolnień, albo uzdolnień kierunkowych, specjalnych, zdolności twórczych, które przejawiają się w wybitnych osiągnięciach. Jest to zespolenie wielu czynników, takich jak: inteligencja, zdolności specjalne, osobowość, środowisko społeczne, aktywność własna, czynnik losowy oraz myślenie twórcze.

W powszechnej świadomości talent jest cechą wyróżniającą się, ponadprzeciętną predyspozycją, umiejętnością specjalną, zdolnością, coś czym można zaskoczyć, tym co człowiek ma w genach, darem od Boga, iskrą bożą, albo darem natury. Do rozwinięcia i kształtowania tych cech potrzebna jest jeszcze ciężka praca i solidny warsztat, aby te cechy, umiejętności, zdolności kształtować. W opinii niektórych respondentów, w rozumieniu potocznym talent jest ponadto pasją, pomysłem na siebie i sztuką realizacji tego pomysłu oraz sprawnością i łatwością w działaniu.

Znaleźli się ankietowani, którzy uważali, że z talentem się trzeba urodzić jednak w większości głosów (45\%) talent jest „wrodzony i kształtowany”. W potocznym mniemaniu talent jest rozumiany jako coś, z czym się rodzimy i co w ciągu całego życia modelujemy, nadajemy kształt. Trzeba zaznaczyć, że potocznie słowo talent jest używane jako synonim zdolności do czegoś. W powszechnej świadomości talent nie jest często kojarzony z wybitnymi osiągnięciami, specjalnymi uzdolnieniami, inteligencją, środowiskiem społecznym, osobowością, czynnikiem losowym itp. Definicja potoczna zawiera w wąskim stopniu część definicji naukowej, ale nie wyznacza głębi znaczenia pojęcia, jakim jest talent. Większość z nas potrafi wyobrazić sobie utalentowane dziecko, jednak czy wszyscy wyobrazimy sobie to samo utalentowane dziecko? Otóż nie, ale większość z nas wyobrazi sobie 
takie cechy, które odróżnią osobę utalentowaną od tej przeciętnej. W formie ciekawostki umieściłam na mapie coraz modniejsze współcześnie pojęcie talentu w organizacji. W lapidarnym skrócie dotyczy kwestii meritum talentów i zarządzania talentami, czynników zwanych facylitatorami talentu (ujawniające i rozwijające talent), różnego postrzegania roli talentów w organizacji, jako problemu i czynnika sukcesu. Innymi słowy talentem w organizacji można nazwać pracownika z dużym doświadczeniem, o wysokim potencjale, z określonymi kompetencjami, umiejętnościami personalnymi. W realiach organizacji tworzone są programy, które pozwalają łowić talenty (talent dany) lub je kształcić (talent nabyty).

Wyniki projektu badawczego opisanego w artykule ujawniają niekompatybilność pojęcia talentu stosowanego w literaturze naukowej i w świadomości potocznej (badanie empiryczne). Właściwe zdefiniowanie talentu jest ważne, ale niezmiernie trudne. Dowodem na to są liczne publikacje, w których autorzy mierzą się z tym pojęciem, uzyskując konsensus jedynie w niewielkim obszarze. W przeciwieństwie do krajów zachodnich (Stany Zjednoczone, Wielka Brytania) polska literatura przedmiotu jest skromna. Nawet w tak wąskim zakresie prace na temat zdolności znacznie przewyższają ilościowo te, które traktują o talencie. Wydaje się, że w Polsce problematyka talentu, a także zagadnienia związane z systemem wspierania i kształtowania zdolności to cały czas terra incognita, która czeka na swojego badacza. Oczywiście nie można nie zauważyć ważnych studiów w zakresie uzdolnień, o czym pisze Krzysztof J. Szmidt w tym tomie.

Celem mojego projektu była diagnoza tego mało zbadanego zjawiska, otwarcie drogi do badań i interpretacji społecznych zachowań, społecznego postrzegania i rozumienia pojęcia wybitnych zdolności i talentu w nowym, współczesnym kontekście. W trakcie analizy materiału empirycznego pojawiła się kwestia definicji talentu funkcjonującej w języku polskim. Konieczne jest rozróżnienie pojęcia talentu i uzdolnienia. Warto pamiętać, że nie należy ich traktować jako synonimy i zastanowić się nad konsekwentnym tłumaczeniem angielskiego słowa gifted jako uzdolniony, a nie utalentowany, a nawet nad ponownym włączeniem do dyskursu naukowego terminów „posiadający dar”, „obdarzony”, co ułatwiłoby rozróżnienie dobrze ugruntowanych w obszarze języka angielskiego pojęć: gifted i talented.

Analiza materiału empirycznego i literatury tematu wskazuje również na konieczność dalszych badań, które mogłyby pomóc w stworzeniu i uruchomieniu mechanizmów wspierających, odkrywających i wzmacniających zdolności. Dzięki wprowadzeniu takiego systemu polskie szkoły stać by się mogły „kuźniami” talentów, a odpowiednie przygotowanie psychologów i pedagogów umożliwiłoby trafną identyfikację zdolności i uzdolnień u najmłodszych.

W chwili obecnej próżnia spowodowana brakiem kompleksowego podejścia do talentu wypełniana jest powstającymi spontanicznie programami medialnymi typu Mam talent. Oprócz funkcji rozrywkowej spełniają one niewątpliwie rolę poznawczą. Niosą jednak także poważne zagrożenia. Przykładem niech będzie przypadek Susan Boyle, 48-letniej gospodyni domowej, która zajęła drugie miejsce 
w finale Britain’s Got Talent. Wieści o niezwykłym darze wokalnym Boyle obiegły cały świat. Zainteresowały się nią media oraz znani aktorzy i wokaliści, m.in. Demi Moore i Ashton Kutcher. Niestety w obliczu nagłej sławy, Boyle przeszła załamanie i trafiła do kliniki psychiatrycznej. Historia Susan Boyle pokazuje, że dar odkryty niespodziewanie i generujący natychmiastową sławę i sukces może być destruktywny dla jednostki i społecznie dysfunkcjonalny. Opracowanie odpowiedniego systemu wspierającego rozwój talentu, w czasie którego człowiek może dojrzeć osobowościowo, stać się w pełni świadomym swojego talentu i przygotowanym na ewentualny sukces bądź porażkę wydaje się nie tylko właściwym, ale koniecznym działaniem w pedagogice. Wydaje się zatem, iż oprócz wybitnych zdolności (talentu) i kreatywności potrzeba nam zespolenia ich z mądrością. Taki jest właśnie jeden z najważniejszych celów edukacyjnych pedagogiki pozytywnej (zob. artykuł K. J. Szmidta w tym tomie).

\section{Literatura}

Achter J. A, Lubinski D. (2005), Blending promise with passion: Best practices for counseling intellectually talented youth, [w:] Career development and counseling: Putting theory and research to work, S. D. Brown i R. W. Lent (eds), Hoboken, NJ: John Wiley i Sons.

Bernacka R. E. (2009), Nie przegap uzdolnień, „Psychologia w Szkole”, nr 1.

Biblia tysiąclecia (2000), Ks. Kazimierz Dynarski SAC (red.), Pallottinum, Poznań.

Bloom B. (1985), Developing Talent in Young People, New York Books.

Chruszczewski M. H. (2009), Profile uzdolnień. Intelektualne i osobowościowe składniki uzdolnień plastycznych i muzycznych, Wydawnictwo Uniwersytetu Warszawskiego, Warszawa.

Csikszentmihalyi M. (1990), Flow, Cambridge University Press, New York.

Dyrda B. (2012), Edukacyjne wspieranie rozwoju uczniów zdolnych. Studium społeczno-pedagogiczne, Wydawnictwo Akademickie „Żak”, Warszawa.

Feldhusen J. F. (1999), Talent and cretivity, [w:] Encyclopedia of creativity, M. A. Runco i S. R. Pritzker (eds), t. 2, Academic Press, Inc., San Diego.

Feldhusen J. F. i Jarwan F. A. (1993), Identification of gifted and talented youth for educational programs, [w:] International handbook of research and development of giftedness and talent, K. A. Heller, F. J. Mönks i A. H. Passow (eds), England: Pergamon Press, Oxford.

Gagné F. (1985), Giftedness and talent. Reexamining a reexamination of the definitions, „Gifted Child Quarterly", nr 29.

Gagné F. (2007), Ten Commandments for Academic Talent Development, „Gifted Child Quarterly”, nr 2.

Gagné F. (2004), Transforming gifts into talents. The DMGT as a developmetal theory, [w:] Handbook of gifted education, N. Colangelo, G. Davis (eds), MA: Allyn i Bacon, Boston.

Gagné F. (2008), Building Gifts into Talents: Detailed Overview of the DMGT 2.0, [w:] Leading Change in Gifted Education: The Festschrift of Dr. Joyce Vantassel - Baska, Waco TX: Prufrock Press Inc.

Gagné F. (2008), Building Gifts into Talents: Brief Overview of the DMGT 2.0, The 10th Asia - Pacific Conference on Giftedness: Nurturing Talents for the Global Community, 14-18 lipca 2008, Nanyang Technological University, Singapore.

Hornowski B. (1978), Rozwój inteligencji i uzdolnień specjalnych, Wydawnictwo Szkolne i Pedagogiczne, Warszawa. 
Kopaliński W. (2007), Stownik wyrazów obcych i zwrotów obcojęzycznych z almanachem, Oficyna Wydawnicza RYTM, Warszawa.

Landau E. (2003), Twoje dziecko jest zdolne, Instytut Wydawniczy Pax, Warszawa.

Limont W. (1994), Synektyka a zdolności twórcze. Eksperymentalne badania stymulowania rozwoju zdolności twórczych z wykorzystaniem aktywności plastycznej, Wydawnictwo Uniwersytetu Mikołaja Kopernika, Toruń.

Limont W. (2010), Uczeń zdolny. Jak go rozpoznać i z nim pracować, Gdańskie Wydawnictwo Psychologiczne, Gdańsk.

Maxwell J. C. (2007), Talent is never enough. Discover the choices that will take you beyond your talent, Nashville, Tennessee: Thomas Nelson, Inc.

Olszewski-Kubilius P. (2003), Gifted eduaction programs and procedures, [w:] Handbook of psychology. Educational psychology, t. 7, I. B. Weiner (ed.), Hoboken: John Willey \& Sons, Inc., New Jersey.

Pietrasiński Z. (1976), Zdolności. Geneza i rozwój psychologii zdolności, [w:] Psychologia, T. Tomaszewski (red.), Państwowe Wydawnictwo Naukowe, Warszawa.

Piirto J. (1999), Talented children and adults. Their development and education, Merrill, New York. Pocztowski A. (red.), (2008), Zarządzanie talentami w organizacji, Wolters Kluwer Polska, Kraków. Popek S. (2003), Człowiek jako jednostka twórcza, Wydawnictwo Uniwersytetu Marii Curie-Skłodowskiej, Lublin.

Popek S. (red.), (1996), Zdolności i uzdolnienia jako osobowościowe właściwości człowieka, Wydawnictwo Uniwersytetu Marii Curie-Skłodowskiej, Lublin.

Rogers K. B. (2002), Re-Forming Gifted Education. Matching the Program to the Child, Great Potential Press. Inc., Scottsdale.

Rubinsztejn S. L. (1964), Podstawy psychologii ogólnej, Książka i Wiedza, Warszawa.

Sękowski A. E. (red.), (2004), Psychologia zdolności. Wspótczesne kierunki badań, Wydawnictwo Naukowe PWN, Warszawa.

Stownik grecko-polski (2001), O. Jurewicz (red.), Państwowe Wydawnictwo Naukowe, Warszawa.

Stownik języka polskiego (1983), PWN, Warszawa.

Strelau J. (1997), Inteligencja człowieka, Wydawnictwo Akademickie „Żak”, Warszawa.

Tannenbaum A. J. (1983), Gifted children. Psychological and educational perspective, Macmillan, New York.

Tiepłow B. M. (1971), Zdolności i uzdolnienia, [w:] Zagadnienia psychologii różnic indywidualnych, J. Strelau (red.), PWN, Warszawa.

Wielki stownik PWN - OXFORD (2006), Wydawnictwo Naukowe PWN S.A. i Oxford University Press.

\section{Strony internetowe:}

http://www.culture.pl/pl/culture/artykuly/os_kobzdej_aleksander http://www.malarze.com/plartysta.php?id=245\&biografia $=\mathrm{f} \& \mathrm{l}=\mathrm{pl}$

http://www.pianostreet.com/smf/index.php?topic $=32875.0$ 